\title{
Analysis of the Formation, Expression, and Economic Impacts of Risk Perceptions Associated with Nuclear Facilities
}

by T. Allison, S. Hunter, ${ }^{*}$ and F.J. Calzonetti ${ }^{\star}$

Economics and Law Section,

Environmental Assessment and Information Sciences Division,

Argonne National Laboratory, 9700 South Cass Avenue, Argonne, Illinois 60439

October 1992 (printed February 1993)

Work sponsored by United States Department of Energy,

Office of Civilian Radioactive Waste Management

*Hunter and Calzonetti are affiliated with West Virginia University, Morgantown, West Virginia. 



\section{DISCLAIMER}

This report was prepared as an account of work sponsored by an agency of the United States Government. Neither the United States Government nor any agency thereof, nor any of their employees, make any warranty, express or implied, or assumes any legal liability or responsibility for the accuracy, completeness, or usefulness of any information, apparatus, product, or process disclosed, or represents that its use would not infringe privately owned rights. Reference herein to any specific commercial product, process, or service by trade name, trademark, manufacturer, or otherwise does not necessarily constitute or imply its endorsement, recommendation, or favoring by the United States Government or any agency thereof. The views and opinions of authors expressed herein do not necessarily state or reflect those of the United States Government or any agency thereof. 


\section{DISCLAMMERR}

Portions of this document may be illegible in electronic image produets. Images are produced from the best available original document. 


\section{CONTENTS}

ABSTRACT $\ldots \ldots \ldots \ldots \ldots \ldots \ldots \ldots \ldots \ldots \ldots \ldots \ldots \ldots \ldots \ldots \ldots \ldots \ldots \ldots \ldots$

SUMMARY $\ldots \ldots \ldots \ldots \ldots \ldots \ldots \ldots \ldots \ldots \ldots \ldots \ldots \ldots \ldots \ldots \ldots \ldots \ldots \ldots \ldots$

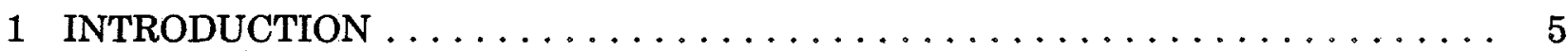

2 LITERATURE REVIEW $\ldots \ldots \ldots \ldots \ldots \ldots \ldots \ldots \ldots \ldots \ldots \ldots \ldots$

2.1 Formation and Expression of Risk . . . . . . . . . . . . . . 7

2.2 Impact of Adverse Risk Perceptions on Local Economic Development . . . . . 12

2.2.1 Importance of Amenities as a Business Location Factor:

Findings in the Literature . ...................... 13

2.2.2 Findings from Research Sponsored by the State of Nevada . . . . . . 15

2.2.3 Argonne National Laboratory Survey of Firms in

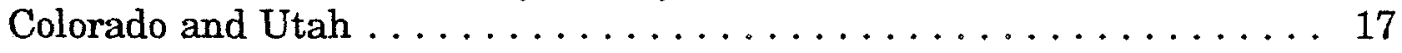

3 METHODS, FACILITIES, AND COMMUNITIES SELECTED

FOR INVESTIGATION $\ldots \ldots \ldots \ldots \ldots \ldots \ldots \ldots \ldots \ldots \ldots \ldots \ldots \ldots \ldots \ldots$

3.1 Research Themes . . . . . . . . . . . . . . . . . . . . 19

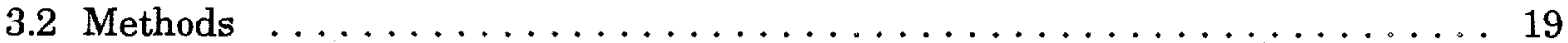

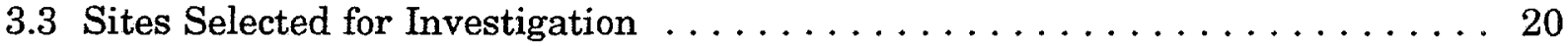

3.3 .1 Commercial Facilities . . . . . . . . . . . . . . . . . . 21

3.3.2 U.S. Department of Energy Facilities . . . . . . . . . . . . 22

4 FORMATION, EXPRESSION, AND MANAGEMENT

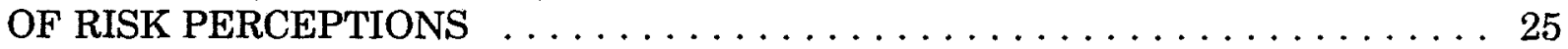

4.1 General Characteristics of Facilities and Local Communities . . . . . . . . . 25

4.1.1 Appearance and Layout of Facilities . . . . . . . . . . . . 25

4.1.2 General Characteristics of Locales Hosting Nuclear Facilities . . . . . 26

4.1.3 Economic Relationships with Local Communities . . . . . . . . 26

4.2 Factors Determining Formation of Risk Perceptions $\ldots \ldots \ldots \ldots \ldots \ldots 28$

4.3 Analysis of Risk Management and Acceptance . . . . . . . . . . . . . 40

5 IMPACT OF ADVERSE PERCEPTIONS ON

LOCAL ECONOMIC DEVELOPMENT $\ldots \ldots \ldots \ldots \ldots \ldots \ldots \ldots \ldots$

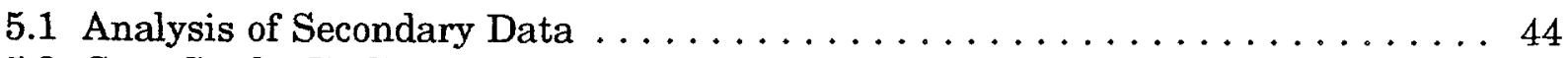

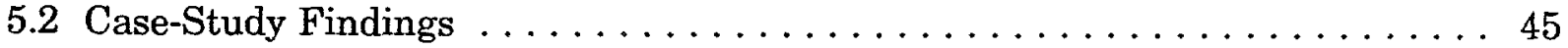

6 CONCLUSIONS AND RECOMMENDATIONS FOR PROGRAMS

FOR SITING NUCLEAR FACILITIES $\ldots \ldots \ldots \ldots \ldots \ldots \ldots \ldots$

6.1 Relationship between Facilities and the Public $\ldots \ldots \ldots \ldots \ldots \ldots$

6.2 Relationship between Facilities and Local Economies . . . . . . . . . . 49 
CONTENTS (Cont.)

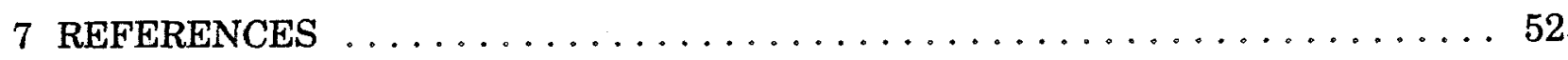

APPENDIX A: Trends in Employment at Nuclear Facilities . . . . . . . . . 61

APPENDIX B: Important Events at Case-Study Facilities: $1970-1989 \ldots \ldots \ldots$

\section{TABLE}

1 Ranking of Nuclear Facilities with Respect to Their Perceived Risk and List of Factors that Contribute to the Risk Perception at Each Facility

\section{FIGURES}

$1 \quad$ Ladder of Citizen Participation $\ldots \ldots \ldots \ldots \ldots \ldots \ldots \ldots \ldots \ldots \ldots$

$2 \quad$ Nuclear Facilities Selected for Perception-Based Impact Analysis . . . . . . . 20

A.1 Trends in Employment in Unicoi County, Tennessee, Host to the Erwin Facility

A.2 Trends in Employment in Lynchburg County, Virginia, Host to the Lynchburg Facility . . . . . . . . . . . . . . . . . .

A.3 Trends in Employment in Massac County, Illinois, Host to the Metropolis Facility . . . . . . . . . . . . . . . . . . . 6

A.4 Trends in Employment in New Hanover County, North Carolina, Host to the Wilmington Facility . . . . . . . . . . . . . . . . . 66

A.5 Trends in Employment in Hartford County, Connecticut, Host to the Windsor Facility . . . . . . . . . . . . . . . . . . . . 67

A.6 Trends in Employment in Hamilton County, Ohio, Host to the Fernald Facility . . . . . . . . . . . . . . . . . . . 68

A.7 Trends in Employment in Montgomery County, Ohio, Host to the Mound Facility . . . . . . . . . . . . . . . . . . . . 69

A.8 Trends in Employment in McCracken County, Kentucky, Host to the Paducah Facility 


\section{FIGURES (Cont.)}

A.9 Trends in Employment in Pike County, Ohio, Host to the Portsmouth Facility ............................. 71

A.10 Trends in Employment in St. Charles County, Missouri, Host to the Weldon Spring Facility . . . . . . . . . . . . . . . . . . 72

A.11 Trends in Employment in Cattaraugus County, New York, Host to the West Valley Facility . . . . . . . . . . . . . . . . . . . . . . . 73 


\title{
ANALYSIS OF THE FORMATION, EXPRESSION, AND ECONOMIC IMPACTS OF RISK PERCEPTIONS ASSOCIATED WITH NUCLEAR FACHITIES
}

\author{
by
}

\author{
T. Allison, S. Hunter, and F.J. Calzonetti
}

\begin{abstract}
This report investigates how communities hosting nuclear facilities form and express perceptions of risk and how these risk perceptions affect local economic development. Information was collected from site visits and interviews with plant personnel, officials of local and state agencies, and community activists in the hosting communities. Six commercial nuclear fuel production facilities and five nuclear facilities operated for the U.S. Department of Energy by private contractors were chosen for analysis. The results presented in the report indicate that the nature of risk perceptions depends on a number of factors. These factors are (1) level of communication by plant officials within the local community, (2) track record of the facility operator, (3) process through which community and state officials receive information and form opinions, (4) level of economic links each plant has with the local community, and (5) physical characteristics of the facility itself. This report finds that in the communities studied, adverse risk perceptions have not affected business location decisions, employment levels in the local community, tourism, or agricultural development. On the basis of case-study findings, this report recommends that nuclear facility siting programs take the following observations into account when addressing perceptions of risk. First, the quality of a facility's participation with community activists, interest groups, and state agencies helps to determine the level of perceived risk within a community. Second, the development of strong economic links between nuclear facilities and their host communities will produce a higher level of acceptance of the nuclear facilities.
\end{abstract}

\section{SUMMARY}

This report summarizes the findings of a series of case studies that investigated how communities hosting nuclear facilities form and express perceptions of risk and how these risk perceptions affect local economic development. The research provides the Office of Civilian Radioactive Waste Management in the U.S. Department of Energy (DOE) with information on the factors influencing the risk perceptions that may arise in communities 
agreeing to host nuclear waste facilities. The study also indicates how these risk perceptions might be reduced and how they will probably affect economic development if risk remains a significant issue in potential host communities.

To provide this information, researchers at Argonne National Laboratory (ANL) examined the impact on the local community of 11 nuclear facilities where the disposal of nuclear waste is an important element of their operations. Local communities seem to perceive the presence of nuclear waste and other nuclear facilities that might cause environmental contamination somewhat differently than they view nuclear power production facilities. Five communities host commercial nuclear fuel production facilities: Erwin, Tennessee; Lynchburg, Virginia; Metropolis, Illinois; Wilmington, North Carolina; and Windsor, Connecticut. Six communities host nuclear facilities that are operated for DOE by private contractors. This second group includes the waste recovery facilities at Fermald, Ohio, and Weldon Spring, Missouri; the uranium products manufacturing facility at Mound, Ohio; the uranium enrichment facilities at Portsmouth, Ohio, and Paducah, Kentucky; and the nuclear waste storage facility at West Valley, New York. ANL researchers collected information on the 11 facilities during site visits and in interviews with plant personnel, officials of local and state agencies, and community activists in the hosting communities.

ANL research found that the nature of risk perceptions and the magnitude and nature of objections to the operation of nuclear facilities depend on a number of factors that had previously been unexplored: level of communication between plant officials and the local community, track record of the facility operator, process through which community leaders and state environmental officials receive information and form opinions on nuclear facilities, level of economic and social links each plant has with the local community, and physical characteristics of the facility itself. Each of these factors has the potential to result in different levels of perceived risk; the actual situation depends on site-specific factors. For example, ANL found that the degree of openness of the operating contractor and its willingness to report accidents and provide information to local groups closely influence the degree of risk that is perceived, and it also found that these factors may influence risk perception regardless of the potential hazardousness of the facility itself. ${ }^{1}$

ANL research indicates that in cases where adverse risk perceptions about nuclear facilities have developed, these perceptions have not significantly affected business location decisions, led to employment losses in the local community, or affected tourism or agricultural development. This situation has occurred not because there is an absence of risk perceptions in the local communities but, more likely, because the potential for nuclear facilities to affect business development and tourism seems to be somewhat limited, primarily as a result of the unattractiveness (to the majority of types of business activity) of the rural areas and smaller cities in which most of the facilities are located. No evidence was found of any negative

1 No evidence of failure to comply with federal and state regulations or compliance agreements was found at any of the facilities. However, risk perceptions may not be formed on the basis of a facility's failure to comply with regulations; they may be linked more closely with the level of trust in which owners and operators of nuclear facilities are held by each of the communities studied. 
economic impact of these facilities; indeed, each facility was perceived favorably by the local community as being an employer and potential contributor to local economic diversification.

This report contains a number of recommendations for nuclear facility siting programs. Because the level at which the facility interacts with community activists, interest groups, and state agencies closely determines the degree of risk that is perceived, to successfully reduce a community's perception of high risk or to maintain its perception of low risk, officials at nuclear facilities need to (1) respond quickly to community concerns, (2) develop a track record of participation in interactive public information programs, (3) have an open and proactive approach to community relations and state agencies, and (4) remain at the facilities they represent for substantial periods of time. The development of economic links between nuclear facilities and their host communities - beyond the use of local labor and basic materials and services - will also result in a higher level of acceptance of these facilities. For new nuclear facilities, the most effective means of developing these economic links would be to search for site locations near smaller urban centers. These centers can often provide the amenities needed to attract the scientific and technical staff that are crucial to the development of new manufacturing and service activities that may be developed close to nuclear facilities. 


\section{INTRODUCTION}

Communities that might otherwise volunteer to host nuclear and other potentially hazardous or unwanted facilities have continually expressed the fear that the incentives and benefits offered them may not be sufficient to offset the impact that risk perceptions will have in their communities. These fears are being expressed at a variety of levels - by community and environmental activists, local business groups, local and state elected officials, the media, and, in some cases, university researchers contracted by state governments. Communities agreeing to host a nuclear waste facility are particularly concerned that perceptions of risk will have significant adverse effects on the present level of both business and tourist activity and that the facility might hinder future economic development efforts.

At the state level, for example, concerns that the construction of a monitored retrievable storage (MRS) facility would lead to significant adverse effects on tourism, business investment, and economic development have resulted in opposition to siting initiatives. In a recent example, New Mexico and Wyoming have opposed further consideration of in-state locations for temporary nuclear storage facilities. Plans to site the permanent waste repository in southern Nevada have elicited significant community and state protests, primarily because it is predicted that significant adverse perceptions will develop as a result of the repository program and that these negative perceptions will adversely impact economic development. Because of these concerns, a significant barrier has confronted efforts to successfully site waste storage facilities - a barrier that will continue to exist in potential host communities if uncertainty continues with respect to the actual impact of waste storage facilities.

Local and state opposition to the repository program in Nevada has often been supported by research programs commissioned by the state of Nevada. These programs focus on the impacts that could result from the perception of risk associated with the Yucca Mountain national repository for disposal of high-level nuclear waste. At other locations being considered for new nuclear facilities, community concern and state government opposition have developed, mostly in the absence of any research or information gathering on the nature and impact of adverse risk perceptions in any of the potential host communities. As a result, community and state concerns have been sufficient to halt nuclear facility siting programs, even though the exact nature and impacts of risk perceptions associated with nuclear waste facilities often have not been fully researched.

This report summarizes the findings of a series of site visits and interviews with plant personnel at six U.S. Department of Energy (DOE) and five commercial nuclear facilities and with local officials and community activists in the hosting communities. The report, based on the analysis of case-study information, also provides initial recommendations of interest to those involved with nuclear facility siting programs.

Section 2 of this report provides a short review of the relevant literature on the formation and expression of risk, with specific reference to work related to nuclear facilities. The literature on the impact of perceived risk and, in more general terms, on the importance 
of environmental amenities and disamenities with respect to the development of industrial activity is also briefly reviewed. Included in this review is a consideration of the research undertaken by the state of Nevada on the predicted effects of the Yucca Mountain project on the economy of the Las Vegas region. Also covered is recent survey-based research conducted by Argonne National Laboratory (ANL) on the importance of amenities and disamenities with respect to the location of manufacturing and service activities in Colorado and Utah.

Section 3 outlines the following major research themes investigated during the course of this project: (1) importance of the influence of facility owners or contractors on the formation of risk perceptions, (2) way in which the information dissemination process influences public trust and confidence, and (3) importance of local economic conditions with respect to the degree of impact that risk perceptions have on local economic development. Section 3 also outlines the methods used to collect information for the case studies. It provides a rationale for the choice of facilities, a description of the main activities at each facility, and a brief summary of the economic features of each community.

Section 4 presents the findings of the analysis of perceptions. The findings are in three sections. Section 4.1 outlines the general characteristics of both DOE and commercial nuclear facilities and the communities in which they are located. Section 4.2 presents the factors that contribute to the formation of risk perceptions at all facilities. Section 4.3 describes how DOE and commercial nuclear facilities have attempted to manage risk and operate in a manner acceptable to the communities in which they are located. Section 5 describes the adverse impact of perceptions of risk associated with nuclear facilities on the economies of the local areas. Section 6 summarizes the findings of the analysis and provides recommendations for nuclear facility siting programs in two parts. It discusses the relationship between nuclear facilities and the public and that between a facility and the local economy. 


\section{LITERATURE REVIEW}

\subsection{FORMATION AND EXPRESSION OF RISK}

The preponderance of literature on nuclear issues deals with nuclear weapons and nuclear war. For example, the Nuclear Psychology Bibliography (Kramer and Moyer 1990) lists more than 3,600 sources, of which only about a dozen refer to domestic nuclear issues (primarily Three Mile Island). These studies focus on the psychological impacts of the nuclear threat and the physical impacts of radiation fallout. They tend to argue that effects from even the threat of nuclear war are severe (Von Greyerz 1962; Smith 1981; Wagner 1985; Solantus and Rimpels 1986).

Over the years, attitudes about the nuclear industry (both nuclear power and nuclear weapons, with their ancillary fuel production and waste disposal facilities) have undergone great change. During the 1940s and 1950s, national security, the Korean War, and the Cold War led to support for secrecy in the nuclear fuel and weapons production areas. President Eisenhower's 1954 "Atoms for Peace" program was also created with a high level of support from the general public (Jacob 1990). Until the 1970s, state and public opposition to nuclear technology was, as Jacob describes it, "timorous and largely ineffective" (p. 31). Government policy during the years immediately after World War II, particularly concerning nuclear issues, was justified on the basis of scientific expertise rather than the democratic process (Nelkin 1981, 1984). Radioactive waste management was characterized by a closed administrative system relying on scientists (McCabe and Fitzgerald 1988).

During the 1970s, a growing interest in environmental issues - together with the Three Mile Island incident, evidence of a government cover-up at Fernald, and the discovery of the danger of radioactive and hazardous wastes at Love Canal, Times Beach, and Calvert City - led to increased public concern about the nuclear industry (Jacob 1990). Studies of Three Mile Island began to focus on the potential psychological and physical effects of living near such a facility (Bromet 1980; Houts et al. 1980; Kasl et al. 1981; Upton 1981; Barlett 1982; Schwebel and Schwebel 1982). As the public became aware that risks were associated with many aspects of the chemical and nuclear industries, researchers began to examine both actual and perceived risks and to investigate federal policies related to environmental protection and risk assessment. Attempts to site an MRS facility in Tennessee drew attention to the diversity of attitudes about nuclear risks within and among communities. As McCabe and Fitzgerald (1988) note, Oak Ridge residents were generally pro-MRS and relatively unconcerned about the risks of nuclear facilities, while many other areas of the state were highly risk averse.

McCabe and Fitzgerald found fairly high levels of support for nuclear facilities in areas where they already existed. There appear to be significant differences in the perception of risk between communities that already have facilities and those that must decide about siting them. A survey of public opinion polls on nuclear power by Freudenberg and Baxter (1984), however, found that the attitude of citizens living near nuclear power plants is changing. A panel study found that $69 \%$ of the residents of Trousdale County, Tennessee, 
supported the local facility in 1979 , but in 1980 , only $45 \%$ supported it. Freudenberg and Baxter also found that the level of support for nuclear facilities from their host communities steadily declined after the Three Mile Island accident. A study of the Diablo Canyon Power Plant by George and Southwell (1986) found that the prime determinants of attitudes about the facility were the respondents' perceptions about health risks, their incomes, and their ages. The amount of information provided affected opinion to some degree but was not significant. As Slovic (1991) found in his research, the level of trust held by the provider of information is another important variable, as is the respondent's experience with the issue. In communities with an existing facility and no history of problems or deception, the level of trust and support should be fairly high. This situation was apparently borne out by a focus group study conducted at Metropolis, Illinois (the site of the Allied-Signal Conversion Facility), by Covello of Columbia University. According to plant manager, Kosmider (1992), the study found overwhelming support for the facility. In communities where a company or government agency has withheld information or where actual problems have occurred (as at Fernald), Slovic (1991) suggests that risk perceptions would also be much higher. Reports from public information directors at the Fernald Environmental Management Project and the Paducah Gaseous Diffusion Plant, both locations of off-site water contamination, bear this out (Kelley 1991; Wattier 1992). Research by Pilisuk et al. (1984) on attitudes toward technological risk in California found that respondents trusted university scientists the most and industry spokespersons the least. There was also little trust in government spokespersons. This research noted that concern for an issue was not reflected in levels of political participation; thus, perceptions of risk may not lead to active opposition to or support for a facility.

Siting of hazardous or nuclear facilities has become an issue, probably as a result of problems at Love Canal, Fernald, and other sites. A body of literature about this issue has developed as well. The "not in my backyard" (NIMBY) syndrome is one widely used variable to explain opposition to the siting of facilities involving even slightly hazardous activities. Downey (1985) contends that the siting of a nuclear waste depository has provided the United States with the "greatest test of American Federalism in the 20th Century" (p. 73) and argues that the issue is really one of shared decision making. A conflict exists between individual and societal interests because local communities must assume the cost associated with waste disposal risks, while the benefits are distributed widely.

The belief that public support or opposition for industrial development in the United States (including the development or continuing existence of nuclear facilities) can be determined solely on the basis of economic factors has been severely threatened by public opposition to a wide variety of development proposals, even in economically depressed areas. Theories that seek to explain such opposition have begun to include social and political impacts as potential variables. Although the issue of jobs and economic stability is always important, in many situations, other factors outweigh economic concerns. The NIMBY syndrome reflects what some scholars describe as postmaterialist values (Inglehart 1977, 1988), what others describe as narrow economic self-interest or irrationality (Wildavsky 1987), and what still others see as a reflection of extreme distrust for government and desire for citizen participation in decision making (Lawler and Parle 1988). 
Although several theories about citizen opposition to or support for siting potentially hazardous facilities exist, most of them involve some form of risk analysis. One form is risk assessment, which is determined by scientific or technical processes and concerns the identification of risks and the estimation of their probability and severity. The other form is risk evaluation, which refers to the process of determining the acceptability of risk (Kraft 1982, 1987). Risk evaluation must consider the perceptions of risk held by decision participants. Risk analysis has been a well-established field since the 1970s (Allison 1971; Tversky and Kahneman 1971; Fischhoff 1977; Fischhoff et al. 1978, 1981; Slovic et al. 1979, 1982a,b; Clark 1980; Schwing and Albers 1980; Kahneman et al. 1982; Freudenberg 1984a,b; Clarke 1988, 1989). Kahneman and Tversky first introduced the idea that risks may not be ascertained equally by all participants in a decision area. Recent work has begun to examine the relationship between established risks and the perceptions of those risks by the general community. Downey (1985), for example, argues that government experts tend to assume a single view of risk, which reflects technical knowledge, while the general public has a very different and more complex notion of risk.

Risk has been examined in the context of actual problems (Carson 1962; Nader 1965; Levine 1982; Clarke 1989; Gamson and Modigliani 1989; Slovic et al. 1991; Pollock et al. 1992), but these examinations were either scientific attempts to delineate actual risk or articles that sought to focus attention on risks not yet perceived. The actual risks associated with some forms of nuclear contamination have been well documented, although risk levels associated with uranium in water, dioxin in air emissions, and many other pollutants are still under investigation. Research on the consequences of low levels of uranium and radium contamination is in progress. Dose response studies on contamination from Fernald are being undertaken by the Center for Disease Control and other facilities, but no data yet exist.

Most risk analysis literature has a psychological bent (Fischhoff 1977; Kates 1977; Cole and Withey 1981; Einhorn and Hogarth 1981; Covello et al. 1982). Many of these authors argue that the media distort data, partly because people cannot organize large amounts of data. Others, such as Douglas and Wildavsky (1982), argue that culturally determined values and phobias play such an important role in risk assessment that only people with pure technical data can be objective.

Tversky and Kahneman first examined risk aversion as a psychological phenomenon in 1971. Bayesian decision theories had made use of probability theory to facilitate decision making (Raiffa 1970, 1984) but had largely ignored the subjective effects of personal risk aversion. Research conducted on the basis of Tversky and Kahneman's prospect theory concluded that people were generally more risk averse about losses than gains, about choices over which they had no control than those they controlled, and about choices involving new decisions than those involving sunk costs. Further research by Slovic et al. (1982a) supports these findings. Slovic suggests that risk aversion is a function of the probability and severity of risk, whether the risk is voluntary or imposed; and that it is a function of the extent to which the risk is fatal, memorable, personally uncontrollable, persistent over generations, and inequitably distributed (Slovic et al. 1982a). Some people are also simply more risk averse than others, according to Tversky and Kahneman (1971). Some recent research 
(Hunter 1992) indicates that environmentalists and environmental protection field workers are more risk averse about all aspects of their personal and public choices than are developers, contractors, salesmen, and scientists.

Although several researchers contend that these differences reflect reactions to media reports, others see cultural values as the primary reason. Some portray the media as purveyors of misinformation (Combs and Slovic 1979; Slovic et al. 1979; Wildavsky 1979; Douglas and Wildavsky 1982), yet even Wildavsky argues that cultural values are the strongest reason for nontechnical perceptions of risk. Pollock et al. (1992) describe three primary theories that explain risk perceptions, particularly those related to nuclear power and hazardous wastes. Inglehart (1990) has proposed a postmaterialist approach to current opposition to nuclear power. He argues that beliefs are shaped in the preadult socialization period. The generation after World War II grew up in a period of economic stability and therefore was less concerned about economic values than the previous generation. These people were able to develop attitudes in favor of nonmaterial values such as environmentalism, personal self-expression, and women's rights. Inglehart contends that people growing into adulthood in times of economic uncertainty will develop much more materialistic values and be more supportive of industry and economic efficiency goals.

An egalitarian approach, described by Rothman and Lichter (1987) and Wildavsky and Dake (1990), suggests that people who hold egalitarian beliefs oppose hierarchical systems of decision making and exaggerate risks taken by governmental agencies that operate with little citizen input. Egalitarians, according to Wildavsky and Dake, generally perceive the dangers of technology to be great and the benefits to be small and thus would oppose nuclear technology on these grounds. People who hold cultural beliefs that support strong individualism also support hierarchical systems of decision making and tend to downplay risks attached to nuclear power, hazardous waste, and other similar issues. Further work by Gamson and Modigliani (1989) suggests that the media are most successful in packaging news when it develops an anticorporate theme. This finding suggests that egalitarian beliefs have tended to be dominant in the American culture of the 1980s and 1990s.

A third perspective, the traditionalist approach, suggests that populist skepticism about science and its consequences explains risk perceptions. Nuclear power and chemical wastes are symbolic of a transition to a technical, impersonal, and secular society that neglects traditional values. This approach suggests that the religious right would likely oppose nuclear power, although there is evidence to the contrary. Pollock et al. (1992) conclude that the egalitarian approach gives the best results when explaining NIMBY syndrome responses to hazardous waste siting. They also state that communities accept hazardous waste siting more frequently than suggested by the media and general literature reviews. Wildavsky (1987) is one proponent of this view. This perspective argues that experts are competent and lay people are generally incompetent. The implication of this argument is that the public should not be allowed to intrude in decision making (Press 1986; Thomas 1986). Both of the above-stated theories or perspectives assume that cultural values determine support or opposition to development. 
In support of the above-stated theories, research on cultural variables by Weenig and Midden (1991) found that the level of cohesiveness within a community affects attitudes about siting decisions. The stronger the communication networks within a community are, the more likely it is that positive information about a facility will be heard and accepted. Weak ties make negative information more likely to be the dominant information perceived.

A fourth theory, proposed by Lawler and Parle (1988), argues that a negative response from the public arises more from risk communication than from risk assessment. They argue, primarily on the basis of U.S. Environmental Protection Agency (EPA) examples, that citizens are more likely to hold rational assessments of risk (views based upon scientific evidence) if they are able to fully participate in discussions before decisions are made. This educationist perspective argues that the public is misinformed and therefore makes poor judgments. EPA public relations documents also support this view (U.S. Environmental Protection Agency 1986). A study of Maine household responses to a radon information program (Smith and Johnson 1988) provides further evidence that new information can reduce perceptions of risk, particularly if citizens are provided with some means of control over the problem. Figure 1 indicates the levels of citizen and most governmental participation activities. As shown, EPA and other government agencies typically engage in what Lawler and Parle (1988) argue are degrees of tokenism rather than degrees of citizen power. Lawler and Parle conclude (p. 18), "Until the elements of dread and cognitive heuristics are addressed in a genuinely participatory process of risk-based decision-making, NIMBY will remain a barrier to solutions to the problems of hazardous waste in the United States."

Rational choice theorists (Allison 1971; Wildavsky 1979; Lave 1984; Meyer and Solomon 1984) argue that risk assessments, which make use of empirical data and expert consensus, can contribute to improved policymaking. These theorists contend that people generally misperceive risks. For example, people overestimate catastrophic risks and underestimate chronic risks, so individual perceptions should not count for much. This approach assumes that risk assessment can be objective, as former EPA Director William Ruckelshaus has argued. Since the early 1980s, the EPA and other government agencies have used cost-benefit analysis and risk assessment to determine whether regulations and government projects should be undertaken. This approach is based on the belief that experts can provide empirical data about the probability of both events and consequences. These data can be used to assign dollar values to costs, risks, and benefits. Mazur (1975) and Clarke (1989), however, provide evidence that risks are seldom, if ever, assessed in a rational manner. Risk assessment has been characterized as an imperfect science (Hattis and Kennedy 1986; Hathaway 1987), in which values are arbitrarily assigned to intangible factors like human life. These studies indicate that risk assessors are selective in choosing their data (i.e., choosing data that support their personal position), so experts often disagree. Data are therefore extremely ambiguous. Silbergeld (1987), for example, accuses the EPA of using unscientific methods and refusing to acknowledge noncarcinogenic risks when conducting risk analyses. On the other hand, Ruckelshaus (1983) argues that it is possible to assess risks objectively. He concludes that public education and a uniform method for risk assessment would solve many of the perceived risk problems. 
Other researchers contend that rational choice approaches to risk assessment assume absolute rationality and ignore social rationality (Perrow 1984; Short 1984). They also state that the acceptability of risk is political (Otway and Thomas 1982; Otway 1987), requiring the values of many different stakeholders to be considered. Some researchers argue that claims of experts to have scientific objectivity are irrational and that social rationality is a more accurate measure of societal values (Commoner 1985; Winner 1985). Hohenemser et al. (1983) and Freudenberg (1988) suggest that the measurement of public concerns could provide a quantitative measure. They contend that more social science input (public opinion and psychological studies) would result in better risk assessments.

The findings discussed in this section suggest that the nature of public information programs may not be sufficient to explain public reactions to proposed or existing hazardous or nuclear waste facilities. The level of trust held by the provider of information, the experience of the public in dealing with the issue, cultural values, economic considerations, and personal characteristics all appear to affect perceptions of risk on a wide variety of issues, including nuclear concerns.

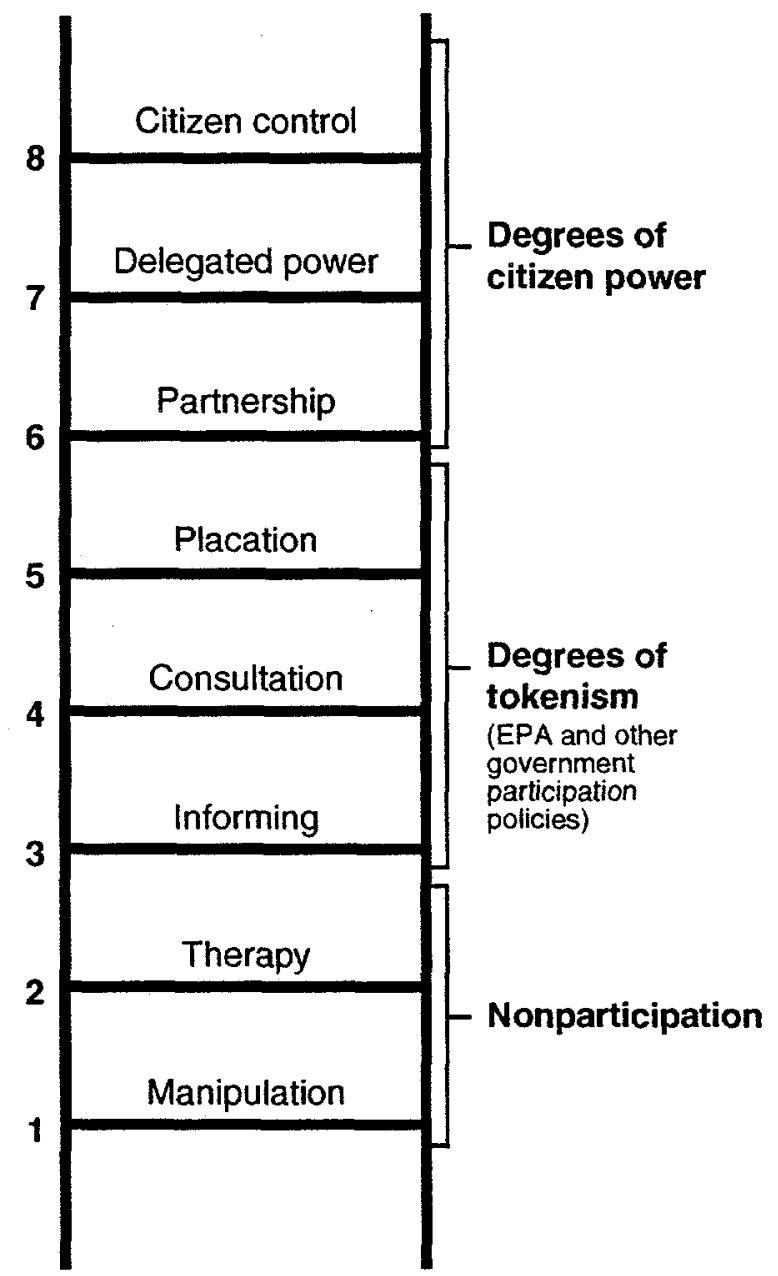

FIGURE 1 Ladder of Citizen Participation (Source: Arnstein 1969. Used by permission of the Journal of the American Institute of Planners. Reproduction without permission is prohibited.)

\subsection{IMPACT OF ADVERSE RISK PERCEPTIONS ON LOCAL ECONOMIC DEVELOPMENT}

The evaluation of perception-based impacts of hazardous waste facilities has become an increasingly important part of socioeconomic impact assessments in recent years (Decision Research and Mountain West Research 1989). One area in which there has been discussion of the potential economic impacts of changes in perceptions of risk and stigma has been business location decision making. This section briefly outlines the findings of research that attempts to link decisions about where to locate manufacturing and business service activities with either (in general terms) local and regional amenities and disamenties or (in explicit terms) perceptions of risk in communities hosting noxious and unwanted facilities. This 
section summarizes (1) academic literature on the role of amenities (including natural, cultural, and recreational features, environmental quality, and other indices of quality of life) with respect to business location decisions, (2) research sponsored by the state of Nevada, and (3) research by ANL on the effects of various disamenities on location decisions and future business location behavior. A more comprehensive analysis of the research in each of these areas is provided in documents by Allison and Calzonetti (1990), Allison (1991), and Calzonetti and Allison (1992) prepared for DOE's Office of Civilian Radioactive Waste Management (OCRWM).

\subsubsection{Importance of Amenities as a Business Location Factor: Findings in the Literature}

Amenities are often cited as being important to industrial location decisions (Smith 1971; Kale and Lonsdale 1979; Ballard and James 1983; Keeble 1989) and are promoted by planners and local authorities as a means of attracting new industry (Burgess 1982; Raitz 1988). Limited empirical work, however, has been published on this issue.

At the regional level, studies of the importance of amenities are often limited by the types of data that are available and can be used to represent the level of amenities in a location. As a result, climatic variables are used most frequently. The lack of plant-level data also limits analyses to making use of regional industrial growth variables as proxies for trends in the location of individual manufacturing plants and business service establishments (Wheat 1973, 1986; Keeble 1980, 1989; Plaut and Pluta 1983). At the metropolitan level, access to recreational amenities is considered a factor in the growth of office space and employment (Ihlanfeldt and Raper 1990). Although results from the above-cited studies show amenities to be somewhat significant factors contributing to growth in office space, some doubt must be cast on the validity of using these results for policy analysis, given the often proxy nature of the variables chosen.

More meaningful analysis of the role of amenities in industrial location decisions would place amenities within the broader context of (1) changes in the orientation of the U.S. economy toward light manufacturing and business services and (2) the impact of these changes on the geographic organization of firms. Changes in the orientation of the economy have placed a different emphasis on factors important to the location of industries and employment, and many firms now have more flexibility with regard to the location of material inputs (supplies). Changes in transportation, technology, and telecommunications have also reduced the costs of marketing many manufactured goods and business services. As a result of these developments, labor costs have often emerged as being the single most important factor to a business that is determining where to locate new activities. Increased locational flexibility has also allowed large corporations to separate functions (such as headquarters, research and development, support services, sales, and production) and choose different locations for each function on the basis of a consequently smaller number of minimal locational requirements. Accordingly, separate functions have developed individual locational patterns. 
For example, corporate headquarters and other high-level business services (such as finance, insurance, legal, advertising, and consulting services) have located in the centers of a small number of large cities. The economics of agglomeration dominate the location of corporate headquarters and associated service functions; of particular importance is the need to minimize the cost of face-to-face contact between high-level executive functions. The decision on where to locate headquarters may also be made partly on the basis of amenities. Schmenner (1982), for example, surveyed corporate headquarters in New England to establish which factors were important to site selection. Schmenner found that when the choice was between regions, markets and labor (wages and labor skills) were most frequently ranked as being important to respondents; amenities (aesthetic quality) were important only to a smaller proportion of respondents. At the local level, when firms were required to choose specific sites for a facility, however, amenities assumed more significance. Burns and Pang (1977) found that amenities were important factors in relocating corporate headquarters from central city to suburban locations. Thirty-eight headquarters facilities surveyed indicated that cultural attractions, university facilities, entertainment, and residential environment were important factors in their final location decision. Likewise, research and development facilities tend to be located at the peripheries of larger urban centers, where proximity to scientific and technical labor and headquarters facilities are the most important location factors (Malecki 1989).

A limited amount of evidence has been collected on the role of amenities in the choice of location for office functions in general, as distinct from headquarters functions. Rhodes and Kan (1971) conducted a survey of 60 commercial offices that had moved either partially or completely from central London in Great Britain. The surveyed managers placed considerable value on the quality of the area surrounding their new location, particularly its lack of a manufacturing base or of the likelihood of one developing in the future.

Other business functions have been located in more peripheral areas and may not be influenced by locational amenities. Routine manufacturing production facilities of larger corporations, for example, are often located on the basis of geographic variations in production labor costs, with the availability of local material and information links and product transportation costs being relatively unimportant factors (Kale and Lonsdale 1979). Likewise, routine data processing functions (back offices) often follow a similar pattern, with labor costs being the primary locational determinant. Often these functions are tied to other corporate locations by telecommunications links, through which relevant data are received and sent (Moss and Dunau 1986).

For a number of manufacturing and service businesses, firm size may influence the geographic extent of the search for a new location and the importance of amenities in the choice of location. For smaller manufacturing firms, the importance of amenities seems to vary according to the spatial scale at which the location decision is made. Spooner (1973), in a survey of key workers and managers in industrial facilities that had moved into southwestern Great Britain, found amenity factors to be more important in a regional than a local search. Stafford (1974), in a survey of manufacturing relocation in Ohio, found that firms conducting a regional search placed more emphasis on amenities when they chose a 
new location. For firms conducting only a local search, amenities were not as important as personal contacts, labor factors, transportation, and markets. Amenities specifically installed to attract new firms were not found to have a significant impact on a company's final decision. Smaller business service firms, on the other hand, are more "locationally footloose" than manufacturing firms, placing more emphasis on locational amenities. Improvements in telecommunications and the growth of contact networking have increased the amount of subcontracting of services by larger manufacturing and service firms to smaller service firms. By subcontracting services, larger firms can locate in more peripheral areas that may also offer a richer amenity base.

Structural changes have also been accompanied by significant shifts in the occupational structure of employment, with a larger proportion of the manufacturing labor force now involved in service occupations rather than in occupations directly associated with production. Significant growth has also occurred in independent business service firms. The separation of activities within many firms and the specialization of functions at each location have also led to a spatial division of labor, in which different functions support certain specialized occupations at different locations. At locations likely to require highly educated labor, decision makers often give careful consideration to the level of amenities available. This situation is particularly noticeable with respect to the location of high-tech manufacturing and service-related activities, including electronic data processing equipment, telecommunications equipment, and consulting services (Markusen et al. 1986; McGregor et al. 1986; Hall et al. 1987; Keeble 1989). Hall et al. (1987) also found that the importance of amenities depends on the type of firm. Multisite and multinational firms rated favorable housing costs and availability, cultural and recreational facilities, pleasant environment, and social relations with others in the same industry as being more significant factors in location determination than did single-site firms.

Amenities may also be important in the success of office-based firms in recruiting and maintaining staff at new and existing locations. Pacione (1982), for example, considered the effect of residential desirability on interregional office relocation decisions and found cultural and recreational amenities to be an important part of the decision to choose a new office location. Ley (1985) assessed how amenities affect employee satisfaction at two metropolitan locations, one downtown and one suburban. Ley found that cultural and recreational amenities were more important considerations at the downtown location, while environmental amenities were more important at the suburban location.

\subsubsection{Findings from Research Sponsored by the State of Nevada}

Although a relatively large body of academic literature exists on the role of amenities with respect to business location decisions, very little research has explicitly considered the role of the adverse perceptions of risk that are associated with nuclear facilities and their impact on businesses and economic development. Research undertaken to date is based on three surveys sponsored by the state of Nevada. Two of these surveys (Center for Survey Research 1988; Decision Research and Mountain West Research 1989) studied attitudes toward and expected behavior with respect to the Yucca Mountain project, and one survey 
considered attitudes in the business community toward the siting of temporary nuclear waste storage facilities in Tennessee.

The repository-related surveys collected information on the individual perceptions of the southern Nevada area as a place to live, work, vacation, attend a conference, and locate a business, both with and without the Yucca Mountain project. A survey of nuclear waste issues (Center for Survey Research 1988) found that without a repository, Las Vegas was viewed as a desirable place to visit or attend a convention but less desirable as a place to raise a family, locate a business, or retire. The average desirability rating declined by $13 \%$ across all questions after the repository was introduced into the interview. When asked whether they would locate a business in Las Vegas after the repository had been built, 57\% of respondents changed their rating.

A survey of corporate decision makers (Decision Research and Mountain West Research 1989) asked 400 corporate real estate executives to describe their images of Las Vegas and to consider if and how proximity to various disamenties (waste and manufacturing facilities) would affect their location decision in a particular community. The results show that business location preferences are fairly predictable and that changes in only one or two of the executives' images could lead to large shifts in their preferences for business location factors.

The third survey, conducted by the University of Tennessee on the possible economic impacts of an MRS facility, found that $37 \%$ of respondents would alter their travel plans to avoid roads with nuclear fuel trucks (Fox et al. 1985). In addition, almost 50\% of respondents noted they would change their vacation destination if they learned that their vacation site was near an MRS facility. In questions related to business location, $55 \%$ of the Tennessee business people surveyed stated that they would not locate in a county with an MRS facility without other overriding positive attributes. In general, business people seemed to believe that an MRS facility would reduce an area's attractiveness as a potential business site.

A number of conceptual problems exist in these surveys. First, the surveys did not examine the attitudes each individual had toward economic development, which may have biased the results toward respondents with definite plans to expand or relocate in the Las Vegas area. These respondents might therefore have overstated their objections to the region as being host to the repository (Clark 1990). Second, the results of the surveys suggest that images of the Las Vegas area can affect preferences for locations for the siting of new business activity. The link between images and actual behavior is tenuous; although changes in images might lead to substantial shifts in preferences, these changes do not necessarily mean that a similar change in actual behavior is likely to result. Third, no attempt is made to distinguish between the differential effects environmental amenities have on the type and level of business activity. Environmental amenities may have an impact on business location decisions in two ways: either directly, through their effect on the personal preferences of entrepreneurs or top-level corporate decision makers, or indirectly, through their influence on a firm's ability to maintain certain strategic occupational groups in a location. 
The quality of amenities in a location may directly affect business location decisions in cases where entrepreneurs or top decision makers decide to move business activities because the siting of a hazardous facility near the existing business location changes their preferences for the region or locale. Specialized corporate facilities and small businesses are most likely to be affected directly by existing levels of amenity provision and changes that may occur through increases in the level of perceived risk. Patterns in the locational behavior of corporate functions with respect to amenities have been discussed above; patterns in behavior in small businesses may be somewhat different. The extent to which small businesses, particularly small manufacturing firms, are affected depends on the resources available to them to search for suitable alternative locations in addition to the cost of acquiring a new facility and moving. Many small firms do not have the resources to conduct a search of alternative locations or access to capital if suitable alternative locations can be identified. It is apparent, however, that smaller producer service firms, particularly those run by highly educated individuals, may respond to changes in the level of amenities and perceived risk in a location more readily than small manufacturing firms. The importance of amenities to specific businesses and industrial activities needs, therefore, to be evaluated with particular reference to a firm's product, technology, organizational structure, and, most importantly, size.

The indirect effect of amenities on business location decisions consists primarily of the effect on location decisions made by individuals in scientific and technical occupations. People in these groups tend to be highly mobile and have been shown to choose locations on the basis of local or regional amenities. Many firms may be indirectly forced to factor the effects of siting hazardous facilities into their location decisions if stigmatization and perception-based impacts lead essential parts of their labor force to migrate from the areas affected. Clearly, the impact of the indirect effect on occupational groups is closely related to the occupational structure of the firms in the affected areas. These occupational characteristics are likely to be related to a number of factors - in particular, the firm's product, technology, size, and organizational structure.

\subsubsection{Argonne National Laboratory Survey of Firms in Colorado and Utah}

Recently, Calzonetti and Allison (1992) compared the roles of environmental and other factors in influencing the location behavior of different types of manufacturing and business service activities. They attempted to obtain information on the importance of amenities in the western states by studying Colorado and Utah. These states were chosen because they compete with Nevada as business locations and have cultural, recreational, physical, and environmental amenities similar to those of Nevada.

In a telephone survey, firms in Colorado and Utah were asked to rank factors in five major groups: (1) labor (cost and quality), (2) communications, (3) market access, (4) taxes and incentives to new businesses, and (5) amenities. They were asked to rank the factors according to how important they would be in both a local and a regional search for a new location. Both manufacturing and business service establishments were surveyed, and 
information on type of plant (headquarters, single-plant establishment, multiplant establishment, research and development facility, back office, etc.) was also collected.

The results of the survey showed significant differences between manufacturing plants and establishments providing business services, with the latter being much more sensitive to amenity considerations. The most important factors for manufacturing plants were low business taxes, cost and availability of suitable premises, and the attitude of state and local government toward business. Quality of education and physical environment were also mentioned as important factors in determining a business location. Plants with fewer than 20 employees rated amenities as an important factor more frequently than did larger manufacturing plants. Smaller manufacturing plants also noted cost and quality of housing as an additional important factor. Across all business service establishments, access to markets was the most important location factor, followed by quality of life, lack of crime, natural environment, schools, climate, and housing. After quality of life and markets, larger service establishments placed more emphasis on premises, government attitudes, and taxes than did smaller firms. For smaller establishments, the emphasis was almost entirely on amenities, with only markets, premises, and government attitudes also included as important location factors.

Significant differences also existed among business activities surveyed, depending on whether the manufacturing plant was a single-plant or part of a multiplant firm or on whether the business service establishment was a single-establishment firm, part of a multiestablishment firm, a headquarters, a research and development facility, or a data processing facility. Results indicate that branch plants of multiplant firms are less sensitive to environmental considerations than single-plant manufacturing or service firms. This result related to the occupational structure in each type of plant. Businesses that require higher levels of scientific and technical support rate amenities as being a more significant consideration in the location of expansion or relocation investment. This rating is particularly evident for headquarters facilities and for a significant number of singleestablishment service firms.

Follow-up interviews with managers and key personnel at both manufacturing and business service firms yielded more information on the role of amenities in the location decision. Although some firms may be attracted to certain amenity-rich locations (particularly locations with a high level of amenities in the natural environment), others may see a potential new location primarily in terms of the need to minimize contact or proximity to certain disamenities, with the need to maximize access to certain amenities as secondary. Results indicate that businesses, particularly manufacturing branch plants and back offices, rate access to amenities as secondary when nonamenity location factors can be satisfied only in a limited number of locations. 


\section{METHODS, FACILITIES, AND COMMUNITIES SELECTED FOR INVESTIGATION}

\subsection{RESEARCH THEMES}

A study of initial case-study evidence revealed that certain factors seem important in determining how risk perceptions associated with nuclear facilities are formed, expressed, and managed. Therefore, case-study information was collected on these factors related to the operation of each facility. The factors considered were as follows:

- The influence of the facility's contractor or operator on risk perceptions. The study examined how owners and contractors at nuclear facilities interact with local and state officials, interest groups, and individuals with respect to the operation of these facilities.

- The nature of information dissemination at nuclear facilities and its influence on public trust and confidence. The study examined how individuals, groups, and state and local officials receive information about the nature of nuclear facilities and its effect on their communities. The credibility of those who provide the information (e.g., facility public relations officers, DOE spokespersons, local officials, or environmental activists) may be an important factor in determining the level of perceived risk within a community.

- The impact of risk perceptions associated with nuclear facilities in different parts of the eastern United States. The study examined trends in the location of manufacturing and service activities, tourism, and agricultural development in the area surrounding each facility.

\subsection{METHODS}

Information on the formation, expression, and management of risk was collected primarily through personal and telephone interviews with on-site personnel, state and local officials, individuals, and representatives of community and environmental groups. Interviewers used a structured questionnaire that was available to potential respondents before they participated in the interview. Each respondent completed a postinterview evaluation of information to ensure the validity of interview results. Additional information was collected from community and state newspaper reports.

Trends in the location of business activity in the area surrounding various facilities were examined through site reviews; interviews with local plant managers, key industry personnel, and local development authorities; and secondary employment data. The study included an analysis of (1) current trends in business location and relocation decisions, (2) the nature of employment and economic development being created and lost, and (3) the sensitivity of business location decisions to actual and perceived changes in environmental 
quality stemming from the facility. The study also evaluated the effects of nuclear facilities on tourism and the impact on the marketing of agricultural products produced in areas near nuclear facilities.

\subsection{SITES SELECTED FOR INVESTIGATION}

The study identified 11 nuclear facilities where the generation, control, and disposal of nuclear waste were important functions of facility operation. Analysis of these sites can show how the nature and impact of risk perceptions differ, depending on the nature of the activity (e.g., commercial fuel manufacturing, weapons components manufacturing, or waste processing), level of activity (e.g., operation or cleanup), contractor conducting the activity (e.g., DOE subcontractor or owner), and the type of local political activity (e.g., community or environmental activism).

The study examined nuclear facilities that have been operating to gauge the impact of these facilities on the surrounding areas and to assess the measures taken to mitigate and manage risk perceptions in each community. Because of travel logistics, the sites selected are in the eastern half of the country. Limiting the sites to this region reduced the geographic variation across the communities, but there were still significant differences in environmental setting. The locations of the selected facilities are shown in Figure 2.

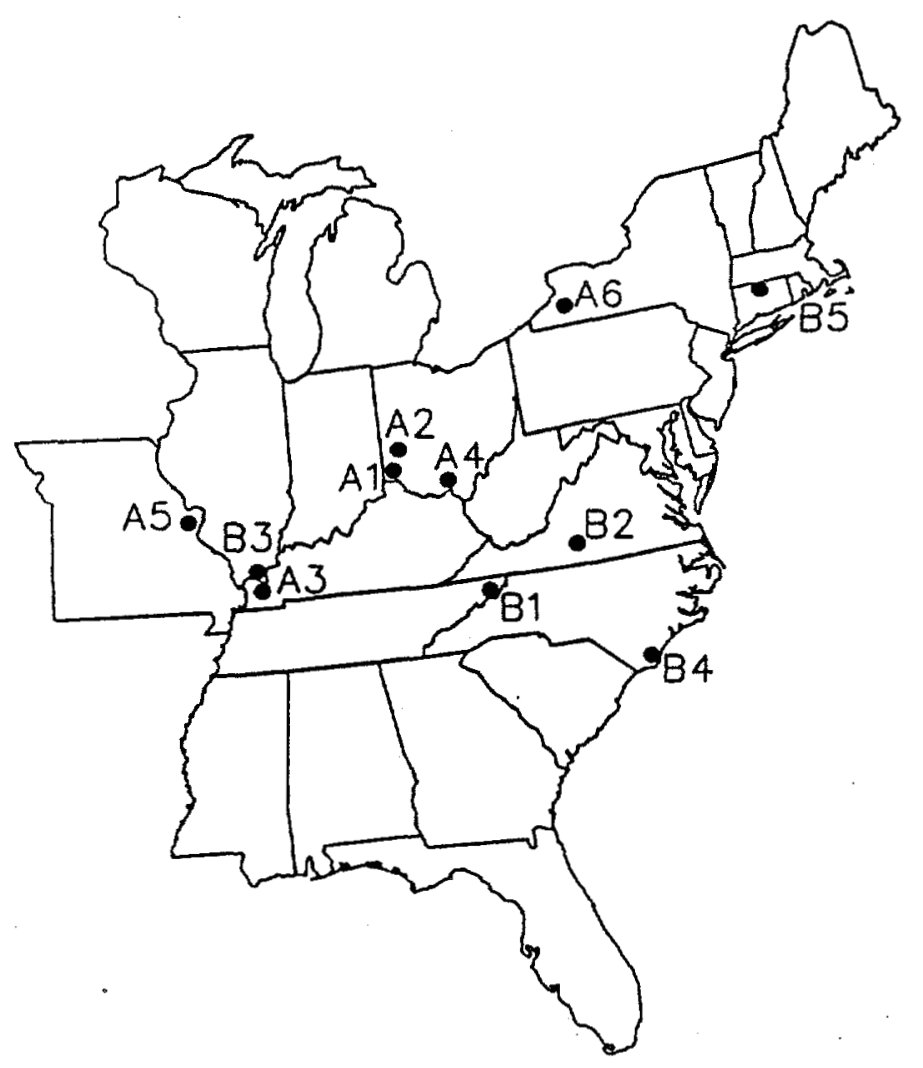

DOE Facilities:

A1 Fernold, $\mathrm{OH}$

A2 Miamisburg (Mound), $\mathrm{OH}$

A3 Paducah, $\mathrm{KY}$

A4 Portsmouth (Piketon), OH

A5 Weldon Spring, MO

A6 West Valley, NY

Commercial Facilities:

B1 Erwin, TN

B2 Lynchburg. VA

B3 Metropolis, IL

B4 Wilmington, NC

B5 Windsor, CT

FIGURE 2 Nuclear Facilities Selected for Perception-Based Impact Analysis 


\subsubsection{Commercial Facilities}

1. Erwin, Tennessee (Nuclear Fuel Services). This facility, built by W.R. Grace, opened in 1956 to provide fuel for commercial nuclear reactors. The facility was also owned by Getty Oil. It was taken over by the present owner, Nuclear Fuel Services (NFS), in 1987. Since 1967, the plant has provided the Navy with fuel for nuclear submarine reactors. The contract at the facility is presently suspended, pending the outcome of defense realignment policies. NFS is attempting to diversify its activities from fuel production and toward environmental services, but the impact on the plant is not known at this time. Erwin (population 5,000) is located in a predominantly rural area in northwestern Tennessee. The plant currently employs 900 people, the majority of whom live close to the facility.

2. Lynchburg, Virginia (Babcock and Wilcox). Two nuclear facilities owned by Babcock and Wilcox (B\&W) are located at the Lynchburg site; one producing commercial nuclear fuel opened in 1956, and one manufacturing fuel for Navy reactors opened in 1968. B\&W was acquired by McDermott, Inc., in 1978. With the loss of the Navy fuel contract in 1992, B\&W formed a joint venture with Framtome, a French company, to provide services to nuclear reactors. Both $B \& W$ facilities are located outside the city of Lynchburg (population 68,000) with other research operations of $B \& W$. The commercial fuels facility currently employs 250 people; the Naval fuels facility employs 2,450 people.

3. Metropolis, Illinois (Allied-Signal). This facility, which opened in 1958, is operated by the Engineered Materials Division of Allied-Signal. It produces uranium hexafluoride $\left(\mathrm{UF}_{6}\right)$ for DOE uranium enrichment facilities at Paducah, Kentucky, and for overseas customers. The facility is located in Metropolis (population 7,000) in an agricultural area on the Ohio River and employs 350 people, or $20 \%$ of the county work force. The facility expanded between 1967 and 1977, but the company now expects to lose jobs as overseas markets for nuclear materials become more competitive.

4. Wilmington, North Carolina (General Electric). This facility, opened in 1968, produces $\mathrm{UF}_{6}$ from uranium dioxide for commercial nuclear reactors, both domestic and international. The plant uses U-235 (enriched to about 5\% U-235 by gaseous diffusion process) as its raw material and converts it to uranium dioxide, which is either sold or further processed into uranium fuel assemblies. GE began reducing its staff at the facility beginning in the mid 1970s, but many employees were transferred to the adjacent GE aircraft engine operation. The facility presently employs 1,080 people. A number of accidents at the 
facility have drawn attention to its nuclear operations. It is located a few miles north of Wilmington (population 55,000), in a semirural section of New Hanover County, a fast-growing residential and tourist area. A commercial nuclear power plant is also located south of the community.

5. Windsor, Connecticut (Asea Brown Boveri-USA). This facility manufactures pellets for fuel rods used in commercial nuclear reactors. Operation started in 1960 . It employs 220 people and is a small part of a larger manufacturing and research operation for electric utilities that employs 3,100 people. The site is a few miles from the center of the community of Windsor (population 28,000) in an area that has changed its economic dependence from agricultural development to commercial, industrial, and residential development.

\subsubsection{U.S. Department of Energy Facilities}

1. Fernald, Ohio (Fluor Daniels). This facility, established in 1951, was designed to produce uranium metal for defense applications. It was originally operated by National Lead of Ohio (NLO). The facility has generated hazardous wastes, and its operation has resulted in groundwater contamination and releases of radioactive substances. The facility has been the subject of legal action, with one suit settled and one pending. The facility ceased production in 1989 when it was taken over by Westinghouse and designated a Superfund site. Fluor Daniels became the contractor in 1992 . The facility employs 1,000 people and occupies a 1,050-acre site close to Ross (population 1,660) in a rural area northwest of the Cincinnati metropolitan area. More than 500,000 inhabitants live within 10 miles of the facility.

2. Mound (Miamisburg), Ohio (EG\&G). Monsanto Chemicals opened this facility in 1936, received a Manhattan Project contract in 1942 and a polonium production contract in 1946, and expanded production to include enriched uranium in 1961. Minor releases of radioactive materials began in 1969, and the public was informed. Monitoring of released materials began in 1979. It began manufacturing nonnuclear explosive components for nuclear weapons in 1980. The present contractor, EG\&G, took over operation in 1988 . The facility employs 2,300 people and is located in Miamisburg, Ohio, a small city in the outer suburbs of Dayton, Ohio.

3. Paducah, Kentucky (Martin Marietta). The facility, currently managed by Martin Marietta Energy Systems, Inc., is an enrichment plant that receives $\mathrm{UF}_{6}$ from Allied-Signal (Metropolis, Illinois) and enriches it by using gaseous diffusion technology. The facility, which opened in 1954, 
was originally operated by Union Carbide, Inc.; management changed to Martin Marietta in 1984. Off-site water contamination problems were first discovered in 1988 . The facility currently employs 1,500 people and is located 15 miles from Paducah (population 27,000), in rural southwestern Kentucky.

4. Portsmouth (Piketon), Ohio (Martin Marietta). This facility, which opened in 1956, uses gaseous diffusion technology to enrich uranium for use in commercial and defense nuclear reactors. Goodyear originally operated the plant, and Martin Marietta assumed control in 1984. The facility currently employs 2,500 people. It is located about two miles from Piketon (population 1,700), in rural southeastern Ohio, and is situated in low hills above the floodplain of the Scioto River. On-site groundwater contamination problems were first encountered at the site in 1978. A strike over employee mobility occurred in 1991 and 1992.

5. Weldon Spring, Missouri (MK-Ferguson/Jacobs Engineering). This site was used by the U.S. Department of the Army from 1941 to 1944 to produce explosives. Control was transferred to the Atomic Energy Commission (AEC) in 1955. While under the control of AEC, Mallinkrodt Chemicals produced uranium metals at this facility until the site was abandoned in 1965. DOE took over the facility in 1985 when it was designated a Superfund site. Large quantities of uraniumcontaminated materials have been dumped in a quarry south of the site, and groundwater monitoring has been necessary. Remediation efforts at the site, which began in the fall of 1992, are likely to employ 250 people when they are fully underway. The facility is located west of St. Louis, Missouri, and is surrounded by a wildlife refuge and an Army training facility. No other activities take place in the area near the site.

6. West Valley, New York (Westinghouse). This facility had its origins in the early 1960s, when the nation's first commercial nuclear reprocessing plant and a shallow-land disposal facility for commercial low-level radioactive waste were constructed. The fuel reprocessing plant was operated from 1966 to 1972 , and the commercial low-level radioactive waste disposal facility was operated from 1963 to 1975 . The site has high-level nuclear wastes from the reprocessing operation, NFSgenerated on-site radioactive waste in an area known as the Nuclear Regulatory Commission-Licensed Disposal Area (NDA), as well as commercial low-level radioactive waste in the commercial State-Licensed Disposal Area (SDA) from a variety of sources including hospitals, universities, and nuclear power plants. Overflow seepage from trenches was noticed in 1975, and the SDA was closed. In 1982, the responsibility for 200 acres of the Center was transferred to DOE for the demonstration project. Currently, the site is being proposed as a 
location for a low-level radioactive waste facility. The site currently has 800 employees. It is located in rural northwestern Cattaraugus County, New York (population 85,700), about 30 miles south of Buffalo, New York. 


\section{FORMATION, EXPRESSION, AND MANAGEMENT \\ OF RISK PERCEPTIONS}

Findings from the case-study analyses of factors contributing to the formation, expression, and management of risk perceptions are presented here in three subsections. Section 4.1 describes DOE and commercial facilities and includes descriptions of the general characteristics of the sites and locales in which the facilities are located and of the economic relationships the facilities have with the local community and region. Section 4.2 presents case-study information on factors identified as having contributed to the formation of risk perceptions related to the facilities. Section 4.3 provides a description of how commercial and DOE facilities have attempted to manage risk and operate in a manner acceptable to the communities in which they are located.

\subsection{GENERAL CHARACTERISTICS OF FACILITIES AND LOCAL COMMUNITIES}

\subsubsection{Appearance and Layout of Facilities}

The appearance and layout of the facilities may have some influence on the local community's perception of risk and level of trust. It seems that public awareness of the nature of activities at each site, approval of the general condition of buildings and other facilities, and access to tours and other on-site activities have a positive impact on risk perceptions in the community.

In general, the commercial nuclear fuel facilities are part of a range of manufacturing operations, and, in all cases, they are perceived by the public in the same manner as ordinary light manufacturing facilities. The appearance and layout of the commercial facilities are also somewhat different from those of most DOE facilities. Buildings seem well maintained and often blend in with the local physical environment, and in the majority of cases, facilities are located close to main roads. In addition, at some of the facilities (e.g., Windsor and Wilmington), recent residential, commercial, and industrial developments have been located nearby - part of the process of suburban growth.

In contrast, many DOE facilities have been sited in relatively remote locations. In the case of Fernald, activists have alleged that the federal government tried to disguise the nature of operations inside the facilities by painting silos red and white. Although this was a Federal Aviation Administration (FAA) requirement, the federal government and the contractor apparently failed to make this fact sufficiently clear to local residents. With the exception of the Mound facility, all DOE sites are located away from major roads and are often enclosed by trees, hidden from view, or placed in isolated valleys with limited access. At the older facilities, lack of Congressional funding during the 1970s, when upgrades were often needed, led to the poor appearance of some of the sites. 


\subsubsection{General Characteristics of Locales Hosting Nuclear Facilities}

The majority of the facilities in this analysis were either established as war-time research facilities, as part of the Atoms for Peace program initiated by the Eisenhower administration in the mid 1950 s, or as part of the drive toward the use of nuclear fuel as a source of domestic energy supply in the late 1950 s and early 1960 s.

Clear differences exist, however, between the sites chosen for DOE facilities and those chosen for commercial facilities. The decisions about where to site DOE facilities were dominated by the (1) level of secrecy required by the proprietary nature of the technology used; (2) need for protection from enemy attack, given the prevailing national security concerns at the times the plants were established; and (3) need to be close to small but stable sources of labor required to staff production activities at the facilities. Four of the six DOE sites studied - the two uranium enrichment facilities at Portsmouth and Paducah, the uranium metals facility at Fernald, and the fuel reprocessing facility at West Valley - were developed at remote greenfield sites by the federal government. The Weldon Spring facility was taken over by DOE in 1985; it had originally been used by the U.S. Department of the Army to produce explosives, with nuclear activities occurring at this site between 1955 and 1965. The Mound facility originally began as a nuclear research establishment and added nuclear materials production activities in the early 1950s.

While the federal government chose somewhat isolated rural communities at which to site nuclear activities, other factors were responsible for the commercial facilities' siting decisions. Three of the five locations chosen for the commercial fuel manufacturing facilities are close to the medium-size population centers of Hartford, Lynchburg, and Wilmington. For the facilities located in these areas, the preference for a remote greenfield site seemed less important than it was for DOE facilities. The remaining two locations are in the smaller centers of Erwin and Metropolis. The NFS facility was located in Erwin in the 1950s as a branch facility of W.R. Grace primarily because of the efforts of an Erwin native. The employee eventually formed NFS at the Erwin facility and later branched out to other locations. The Metropolis plant has a more remote location than many commercial nuclear fuel facilities. It is located at the site with two other divisional operations of Allied-Signal. Despite the initial expectation that secrecy and security concerns would dominate the location decisions of nuclear facilities, and the fact that siting agencies could choose remote locations because nuclear products are of high value compared with the per-unit costs of transportation, case-study evidence suggests that nuclear facilities might also be able to locate closer to smaller urban centers.

\subsubsection{Economic Relationships with Local Communities}

A second characteristic that may be an important contributing factor to the nature of risk perceptions is the extent to which nuclear facilities have successfully fostered economic links with the local and regional economies in which they are located. Facilities that are relatively isolated from local community economies may be perceived less positively than those that have attempted to closely integrate their activities with local businesses and draw 
their skilled labor from the local economy. With the exception of the Mound facility, all DOE facilities in this case-study analysis had very limited local economic links with the communities in which they were located. The two uranium enrichment facilities are perhaps the best examples of the lack of local links. Both plants created considerable employment opportunities during their construction in the early 1950 s and led to significant in-migration to both communities. Local businesses expanded to serve the construction workers, and the communities subsequently built additional housing. Since the completion of both plants, however, there has been little interaction with other businesses in the communities of Piketon or Paducah beyond the provision of basic services to the plants. The most significant impact of both plants has been on local employment, with 2,500 people working at Portsmouth and 1,500 people working at Paducah. Although these people are often working at skilled and semiskilled jobs, at Portsmouth, there is an increasing concern that the likely closure of these facilities will leave workers with skills that are not transferable to other local business activities and that local resources will not be able to generate the necessary replacement business activities.

The lack of economic links at Portsmouth and Paducah is perhaps typical of large manufacturing establishments located in small communities. Several factors - a stable local labor supply (the recent strike at the Portsmouth facility perhaps indicates a deterioration in this situation), dependence on national rather than regional markets, and overriding national security concerns drove production decisions when the plants were located - could have precluded significant local interaction. Lack of either local or regional suppliers and the relatively high level of specialization in every part of the production process have perhaps also limited local economic integration.

The other DOE facilities at Fernald, West Valley, and Weldon Spring have somewhat limited economic relationships with the communities and regions in which they are located. The Fernald facility was originally developed on a greenfield site in the early 1950 s, but it is now close to the outer suburbs of Cincinnati; the local community of Ross is likely to be developed for residential and commercial purposes in the near future. While this case-study analysis has not fully revealed the exact nature of economic links with the local community and how these links have changed over time, it seems that during its early years, the Fernald facility may have had, at best, links with suppliers in Cincinnati and other parts of southern Ohio. The small size of the local community throughout the life of the plant has meant that skilled and managerial personnel have commuted to the plant from elsewhere in the region. Recently, however, these links have become more locally based. For the Weldon Spring and West Valley sites, the extent of local links has been particularly weak, partly because of the undiversified local economy and the lack of suitably skilled people and, in the case of Weldon Spring, the relatively small size of the facility.

The Mound facility in Miamisburg is the only facility that seems to have fostered relatively strong economic links with the local community. This situation may have occurred partly as a consequence of the plant's original mission as a research facility. Although the plant produced materials that were subject to secrecy and national security concerns, because Monsanto already owned the site, a remote location was not chosen, as was the case for the 
other DOE facilities. Production of nuclear materials (polonium and later enriched uranium) has continued at the facility despite its location immediately adjacent to the town.

Except for the Metropolis and Erwin facilities, the commercial facilities seem to have fostered fairly strong links with their host communities. These links include not only the use of local skilled and semiskilled personnel and services (as in the case of Windsor) but also diversification by the company itself from fuel production activities and into research and development and computer hardware and software consulting (as in the case of the Lynchburg facility). At the Wilmington plant, General Electric has been scaling down its nuclear operations throughout the 1980s but has maintained its total site work force by transferring many employees to the aircraft engine manufacturing plant that was located at the site in 1980. The Metropolis and Erwin facilities are somewhat different from the other facilities. Nuclear activities at the Metropolis facility are part of chemical and oil company operations, and nuclear operations are viewed by the company as an integral part of chemical production activities. With respect to Erwin, although NFS started at this location, diversification into other activities (e.g., environmental services) has occurred, but at other locations of the firm, possibly in an effort to tap into more specialized labor markets elsewhere.

An explanation for the differences between DOE and commercial facilities with respect to the economic relationships they have with the local community lies in the different missions of the two types of organizations. There may be considerable incentives for a company running a commercial fuel plant to keep it open, even if the activity for which it was originally built has become unprofitable. Considerable capital costs have been incurred at each of these facilities on buildings, the plant itself, and equipment; therefore, alternative uses for these investments are likely to be closely evaluated, including any opportunities for diversification from fuel production activities that might exist locally. At DOE facilities, decisions made about the orientation and future of operations are likely to be based on political choices rather than the need to recover capital costs through the diversification of activities at each site.

\subsection{FACTORS DETERMINING FORMATION OF RISK PERCEPTIONS}

This study found great variations in the attributes of the local communities, the local physical environment, and the characteristics and operation of the nuclear facilities across the 11 communities investigated. Given these variations, it is difficult to provide general findings that are not locally unique and that will be useful for nuclear facility siting programs. To illustrate the degree of variation in characteristics across each case study, Table 1 lists the attributes of the communities and the characteristics of the facilities. It shows factors in the physical environment, local socioeconomic conditions, the history of the operation of the facility, the nature of state and local relationships with the operators of the 
TABLE 1 Ranking of Nuclear Facilities with Respect to Their Perceived Risk and List of Factors that Contribute to the Risk Perception at Each Facility
Rank and
Facility
Location
Contributing Factors

High risk

Fernald,

Ohio
Negative:

- The facility is perceived as withholding information from the public.

- Pollutant emissions have actually been detected at the facility.

- The facility has allegedly failed to inform every interested party about water contamination.

- A class action lawsuit against the facility was settled for $\$ 78$ million.

- An attorney has instituted an employee class action lawsuit against the facility.

- The state of Ohio has attempted to fine the facility.

- A community interest group has been organized as the result of environmental problems at the site.

- The facility is a Superfund site.

- Key DOE public relations personnel have frequently been moved to and from other DOE sites.

- The facility has kept old middle management.

- The EPA has made efforts to fine the plant.

- Attempts to move waste off the site have caused problems.

\section{Positive:}

- Westinghouse and now Fluor Daniels have been trying to change the public's perceptions about the plant.

- The facility is no longer actively engaged in production.

- The facility is some distance from a metropolitan area.

Moderate risk

Paducah,

Kentucky
Negative:

- Six off-site wells have been contaminated. 
TABLE 1 (Cont.)

Rank and

Facility

Location

Contributing Factors

Moderate risk

(Cont.)

Paducah,

Kentucky (Cont.)
- The facility did not open proactive communication with the community until the 1980 s.

- The proposed MRS in nearby Calvert City has raised environmental concerns.

- A local industrial park is contaminated.

- Responses from DOE have been inconsistent across DOE sites.

- The probability is high that the plant will close.

Positive:

- The facility responded immediately to well-water contamination.

- The lawsuits were settled right away.

- Martin Marietta openly communicates with the community.

- The facility is economically important to the community; it provides half of local manufacturing jobs and pays high wages.

- The facility is in a stable, older community.

- Employees have not instituted a union strike since the 1970 s.

Portsmouth, Negative:

Ohio
- On-site groundwater contamination was discovered in 1979.

- Until recently, information on pollutant releases was not proactively communicated to the public.

- An attorney is trying to institute a class action lawsuit against the facility.

- Reporting on the facility by the Columbus newspaper has been very negative.

- A long union strike was only recently settled.

- The labor environment is negative. 
TABLE 1 (Cont.)

Rank and

Facility

Location

Contributing Factors

Moderate risk

(Cont.)

Portsmouth, Ohio Positive:

(Cont.)

- Management is very open; tours of the facility are given.

- The facility has a positive relationship with the state.

- The facility is economically important to the city.

- There has been no proof of any environmental damage resulting from the facility.

- The facility is in a generally stable, older community.

West Valley,

New York
Negative:

- Incidents of waste contamination can be traced to 1975 .

- Several active citizens groups oppose expansion of the facility.

- Some claim the facility has caused health damage and property losses.

- There is controversy over the proposal to build a low-level waste disposal facility at the site.

- The community fears that further development of the facility will cause local property values to decrease.

Positive:

- The governor of New York supports this location as a disposal site for low-level waste from hospitals and power plants.

- Westinghouse has improved public relations efforts; it has had open houses at the facility.

- County and state economic development personnel do not predict the facility will have a negative effect on the community.

- The area is experiencing a growth in tourism despite the presence of the facility.

- The facility is located some distance from a metropolitan area. 
TABLE 1 (Cont.)

Rank and

Facility

Location

Contributing Factors

\section{Low risk}

Erwin,

Tennessee

Lynchburg,

Virginia
Negative:

- The facility was first owned by an oil company.

- Some activities at the site are still considered secret; open access is not provided to all parts of the site.

Positive:

- There are no interest groups opposed to the facility.

- The facility is not a Superfund site.

- The facility is in a retirement community.

- The facility employs many county residents.

- The facility promotes public relations efforts; tours are given.

- A white-water rafting group sponsors activities in the river running alongside of the facility.

Negative:

- An antiwar (i.e., antinuclear) group demonstrates in the local area.

- Disagreement exists within the state environmental protection agency about the need for monitoring procedures at this facility.

- The facility manufactured some of the parts used in the reactor at Three Mile Island.

Positive:

- The facility is important to the area economy.

- The facility has had very good public relations since the $1950 \mathrm{~s}$.

- The company has diversified its business activities in the local area. 
TABLE 1 (Cont.)

Rank and

Facility

Location

Contributing Factors

Low risk (Cont.)

Mound,

Ohio

Negative:

- Attorneys have organized a local group of citizens who are opposed to this facility.

- The facility is a Superfund site.

Positive:

- Community residents need the jobs the facility provides.

- There has been no evidence of any harm resulting from the facility.

- DOE personnel are responsive in dealing with community concerns.

- The facility has maintained a good relationship with the EPA.

- The facility has maintained a good relationship with the state.

- Property values in the area are high.

Metropolis, Illinois Negative:

- The facility is losing business to European competition.

- The soil at the facility is contaminated; although the contamination was caused by the previous owner, it is the responsibility of AlliedSignal to clean it up.

Positive:

- No contamination has resulted from Allied-Signal plant operations.

- The facility is still a major employer in the community.

- The facility has maintained a good relationship with the community; it has established a neighborhood council.

- The facility is located in a stable, older community.

- In general, chemical companies have a better reputation than does DOE. 


\section{TABLE 1 (Cont.)}

Rank and

Facility

Location

Low risk (Cont.)

Weldon

Spring,

Missouri
Negative:

- The facility is a Superfund site.

- The facility has significant on-site contamination.

- The facility does not contribute significantly to the local economy.

- A small citizens' group is demanding stricter controls on the water treatment plant on the site.

\section{Positive:}

- The site has been closed for 20 years.

- Contamination at the site preceded nuclear operations.

- The press has not focused attention on the site.

- The facility is in a rural area; few people and businesses are affected.

Negative:

- Several on-site nuclear accidents have drawn attention to the facility.

- Newspaper publicity has not been positive toward nuclear power, partly because the Brunswick nuclear power plant is located nearby.

\section{Positive:}

- The facility is a dominant employer in the area.

- The facility has made good efforts to communicate with the community.

- The facility is viewed as a manufacturing as well as a nuclear operation. 
TABLE 1 (Cont.)

Rank and

Facility

Location

Contributing Factors

Low risk (Cont.)

Windsor, Connecticut
Negative:

- The facility is in an area that is growing rapidly; problems could arise in the future.

Positive:

- The facility is not viewed as a nuclear operation, but as a manufacturing plant.

- The facility is attractive and in an industrial/commercial district outside the town.

facility, and the nature of nuclear operations that may affect the level and impacts of risks that are perceived at each of the facilities. The table ranks the facilities according to the level of risk perceived in each community and lists factors that have affected the level of these risk perceptions.

The perceptions of risk at each facility - by the local community and by the state agencies - seem to vary considerably among sites (in particular among DOE sites) and also between DOE and commercial facilities. Community perceptions of DOE facilities are somewhat uncertain. For most DOE sites, community members seem to realize that the facilities are significant contributors to local employment, but opinions of the facilities and the way they have been managed (in particular the opinions of communities and state agencies) differ markedly among DOE facilities. In contrast, the commercial fuel production facilities considered in this study are viewed favorably by the communities in which they are located; very low levels of risk are perceived, despite the environmental problems and consequent local press coverage encountered at one of the facilities.

The most important differences in risk perceptions associated with the facilities examined seem to be between those associated with DOE facilities and those associated with commercial facilities. These different risk perceptions seem to have resulted, in particular, from the different processes by which owners and contractors interacted with local and state officials, local interest groups, and individuals concerning the operation of these facilities. Monitoring of air and water at both federal government and commercial facilities was not required throughout the $1940 \mathrm{~s}, 1950 \mathrm{~s}$, and 1960s. Since the passage of the 1970 Clean Air 
Act and Clean Water Act, there have been significant monitoring-requirement differences between DOE and commercial facilities. Under the two acts, commercial facilities are required to monitor air and water emissions, but federal facilities gained an exemption from these requirements. Nonetheless, during the 1970 s and early 1980 s, most contractors at the DOE facilities studied stated that they had voluntarily complied throughout this period. However, it has been suggested that because there were no reporting requirements and because DOE was not required to provide other federal and state agencies with access to its facilities, the quality and extent of monitoring at DOE facilities has tended to vary. More stringent monitoring and reporting standards for DOE facilities were set under the provisions of the national pollutant discharge elimination system (NPDES) in 1987, and a 1992 Supreme Court decision gave federal agencies the right to take legal action against DOE to ensure compliance with environmental regulations.

Although there was no evidence of failure to comply with federal and state regulations or compliance agreements at any of the facilities studied, risk perceptions may still be associated with these facilities, because risk perceptions may not be formed on the basis of a facility's failure to comply with regulations. Perceptions of risk are more closely linked with the level of trust in which owners and operators of nuclear facilities are held by each of the communities studied. In this respect, it seems that (1) the exemptions gained by federal facilities in the 1970s and 1980s from monitoring and reporting requirements (before the changes under NPDES) and (2) the role of other federal and state agencies in ensuring compliance have contributed to the development of mistrust of DOE at a number of sites, particularly at Fernald.

In addition to experience at DOE facilities with monitoring and reporting requirements, a variety of events at a number of the DOE facilities studied have also tended to worsen perceptions of risk held in communities surrounding these facilities. During the latter half of the 1970s, when many of these DOE facilities, particularly Fernald, were in need of repairs and upgrades, the Carter Administration and Congress cut funding for nuclear programs. This situation meant that many necessary equipment replacements did not occur. The deterioration of equipment and lack of outside monitoring led to suspicion of wrongdoing on the part of some state personnel and citizens' groups. This suspicion was enhanced because there were changes in contractors at many facilities in the $1980 \mathrm{~s}$ and because of DOE's practice of moving key personnel between sites. As a result, communities often had no long-term contacts in whom they trusted to provide reliable information about emissions or other problems at these facilities. Middle management at most sites were often first employed during the 1950s or early 1960s, when a high degree of secrecy did exist about nuclear technology and the exact activities at the sites. These older personnel were less willing to provide open access to their facilities than were people hired in the 1970s or 1980s. Public relations had not been a part of the mission of the DOE facilities when they were constructed, and these facilities were slower to develop these programs than were commercial facilities, which had been forced to respond to the environmental concerns of citizens during the 1970s. To further complicate matters, the uranium enrichment facilities will be turned over to a public corporation in 1993 , so it is likely that a different set of personnel will be handling public information issues. 
Also during the mid 1980s, local community activists (in particular FRESH Fernald Residents for a Safe Environment) were organizing with the help of a local Cincinnati lawyer. The class action lawsuit that ensued at the site as result of problems at the plant has recently been settled out of court for $\$ 78$ million as compensation for psychological rather than actual harm. Former workers are currently attempting to fine the plant (DOE and contractors), and the Ohio Environmental Protection Agency has attempted to fine DOE in the past. The lawyer involved in the Fernald lawsuit has subsequently become involved in organizing class action lawsuits at Portsmouth and Mound. The number of lawsuits against DOE and its contractors has apparently led to the heightening of risk perceptions about nuclear facilities in general and about DOE as a communicator of risk in particular. The only mitigating circumstances at Fernald helping DOE to offset the very negative perceptions the community has of the facility are the curtailment of nuclear production activities at the site and the designation of the facility as a Superfund site in 1989. (Paradoxically, at other sites, these items can worsen perceptions of risk.) The change of contractors in 1989 may also have had the effect of mitigating risk perceptions, although the impact of this development is not clear at this time.

Of the sites examined, Fernald seems to represent an extreme case, with the serious environmental problems at the plant apparently being exaggerated by poor communication between DOE and the public, state agencies, and the state legislature. The class action lawsuit at Fernald seems to have resulted in two perceptions about other facilities in Ohio (Mound and Portsmouth): (1) there is a potential for significant environmental impacts at nuclear facilities, and (2) it is likely either that information on these impacts has been concealed from the public or that impacts have not been properly monitored. These beliefs have led to adverse perceptions about DOE as a site manager, although, in general terms, DOE policies on emissions monitoring and information dissemination tend to vary considerably among sites. Other DOE sites (Paducah in particular) have tended to favor more timely dissemination of better information, but they may still suffer because of DOE history at Fernald.

Contamination has occurred at the other DOE sites at Mound, Paducah, Portsmouth, West Valley, and Weldon Spring, but perceptions of these facilities and the related problems are somewhat different from those of Fernald. At Paducah, a number of events have occurred that have had potential to negatively affect the perception of risk. There has been concern in the community over a proposal to site an MRS facility in Calvert City and over the existing contamination of industrial park facilities. The enrichment facility itself has also contaminated local residential wells with radioactive material. Furthermore, from the beginning of operations, it has been alleged that there was a lack of adequate monitoring of water quality combined with a lack of open communication with the public. Although DOE's response to radioactive contamination was initially slow, it seems that once the seriousness of problems at the site was recognized, DOE's response was immediate and effective; it paid for the bypass of the affected wells and their replacement with city water for all affected parties. The responsiveness to community concerns by DOE and the present contractor at Paducah, the promotion of open communication of information with the public, and the importance of the facility to the local community (in providing half the local manufacturing 
jobs) seem to have elicited fairly favorable perceptions of risk in the community and state. Uncertainty, however, surrounds the future of uranium enrichment by DOE at the plant as well as the size and nature of activities if the facility were transferred to a public corporation; this possibility may have contributed to heightened adverse perceptions in the community.

Perceptions of risk about the facility at Portsmouth are somewhat different from those about Paducah. This difference seems to be related to recent events at the plant rather than directly related to significant cases of mismanagement or emissions reported at the plant. The communities at Paducah and Portsmouth share many of the same characteristics - both are stable, with relatively older populations, and both economies are relatively small and undiversified, with the enrichment facilities in both communities dominating the local economies. The contractor at the Portsmouth facility is open, gives tours of the plant to the public, and has a positive relationship with state environmental agencies. As was the case with Paducah, the Portsmouth facility had early problems with contamination and releases to the environment allegedly not being properly monitored and reported to the public. However, no proof of damage to the environment has been discovered to date. In terms of factors likely to significantly affect risk perceptions, the major difference between the two facilities seems to be the recent strike at Portsmouth, which focused on mobility among jobs at the plant. This strike, combined with fears about the future of the facility and U-AVLIS (the new uranium enrichment technology), has resulted in less favorable perceptions of the facility.

Another difference between the two facilities may be the latent concern over safety at Portsmouth, where a class action lawsuit is being developed. This lawsuit is likely to focus on the issues of sovereignty and equity rather than on the extent and quality of environmental monitoring and information dissemination. Because the settlement at Fernald was for psychological rather than actual harm to the community and because the same law firm that successfully brought the class action suit at Fernald is involved at Portsmouth, more opportunities may exist for the community at Portsmouth to express adverse perceptions than is currently the case at Paducah. Identification of environmental problems by the media has also exaggerated the problems faced by DOE and, to a lesser extent, the contractor, once problems have been identified. The growing attention the Portsmouth plant is receiving from the Ohio EPA, together with the reputation DOE has as a result of events at Fernald, led to a series of negative reports in the Columbus newspaper. Many of these reports focused on legal requirements to monitor emissions at DOE facilities. Although DOE is not required to monitor emissions under the 1970 Clean Air Act, it has done so voluntarily, but it often has allegedly not reported its monitoring activities to the public. At Fernald, this situation has been found quite clearly to be the case. At Portsmouth, the facility did not proactively release to the local community information on emissions deemed to be nonthreatening. The level of reported monitoring clearly influences the level of risk perceived by the public, as does the timing of compliance with existing environmental regulations; DOE has been found to be lacking in both respects at Fermald. In addition to the complete lack of monitoring, the lack of systematic monitoring may also explain the slightly higher risk perceptions at Portsmouth. 
At West Valley, contamination of water from leaking underground tanks was first detected in 1975, and DOE assumed responsibility for the site in 1982. Although the facility itself is relatively small when compared with the other DOE facilities, it is a significant employer in the local community. Perceptions of risk associated with the site have been heightened recently by attempts by the state of New York to site a low-level waste facility at the site. Considerable uncertainty surrounds the future of the facility. Legislation on the new facility, which carries the support of the governor's office, is pending approval in the state congress. Several active citizens groups oppose the new facility and claim health and property losses as a result of contamination and stigma.

Of the six DOE sites, only the Mound facility and the Weldon Spring facility seem to be perceived as having a relatively low level of risk. Mound has had contamination problems since the 1960s; monitoring at the plant began in the late 1970s. The facility has been designated as a Superfund site, and lawyers have organized a local opposition group. However, the plant has developed a good relationship with the state EPA and state legislature. At Weldon Spring, perceptions of risk associated with the facility do not seem to be very significant, although it has had considerable on-site groundwater contamination. Production activity ceased at the site in 1965 . From then on, the site was virtually abandoned until its designation as a Superfund site in 1985. Remediation efforts at the site are likely to employ only about 250 people; very little economic activity surrounds the site, and the facility makes little or no contribution to the local economy. In addition, no off-site contamination has been found at the site.

At the commercial fuel manufacturing facilities, the general reputation of the companies that are running the facilities as diversified engineering and chemical manufacturing organizations seems to have produced a fairly positive perception of the operation of the facilities on the part of the community and state. Generally, the public perceives that each of the plants has a relatively high level of managerial and technical expertise in a range of areas, in addition to nuclear technology, and this belief has generated a relatively high level of trust. Individuals and state agencies seem more willing to trust each company to run nuclear operations safely. If an accident were to occur, they would have some confidence that the companies would respond in a timely and effective manner and keep the public informed.

Commercial facilities are subject to different environmental monitoring and reporting requirements than DOE facilities. Commercial facilities are required to comply with conditions of the 1970 Clean Air Act and have been required to collect a longer history of data on releases than have DOE facilities; they have also been required to provide this information the public. DOE facilities have often undertaken voluntary monitoring and public information programs, but these have allegedly often been insufficient, and many took place after releases had occurred. In addition, DOE facilities did not hold public hearings until the 1980s, which, in the case of Fernald, Mound, Paducah, and West Valley, was some time after emissions had been detected. The lack of legal requirements to meet clean air and water standards has in itself, however, led to community concerns in spite of voluntary DOE efforts at most of the facilities. 
The companies running the commercial facilities seem to realize the benefits of participation in risk communication programs as part of public relations. Early and effective public outreach programs have paid off for the commercial nuclear fuel facilities, as has the timing of compliance at these facilities where problems have developed. The facility at Wilmington, for example, has had a number of problems with accidental releases and employee malcontent since the mid $1980 \mathrm{~s}$, and these events have received attention in the local press. In 1985, a U.S. Nuclear Regulatory Commission (NRC) inspection criticized GE's reactor materials operations for its quality control program and attitudes toward safety at the plant. On a number of occasions, however, the company has gone beyond its legal reporting requirements. The company is also active in local community education programs. Hence, the perception in the community remains one of trust in the company, although recently, the local press has been critical of nuclear technology in general as the result of a series of mishaps at the nearby Brunswick nuclear power plant.

Another important part of the difference between DOE facilities and those run by commercial companies that affects risk perceptions is the attitude toward risk communication. At the Portsmouth facility, concern over safety and trust in facility management has increased because of class action efforts at Fernald. Adverse perceptions of nuclear facilities seem to spread from facilities where there have been problems to other facilities, even if facilities subsequently affected are operated by different contractors, and even if the interaction between the contractor and community and state agencies has been more timely and comprehensive. At commercial facilities, the level of risk communication has been far superior to that at DOE plants; they have informed the public of any new developments, positive or negative, at the plants. Interviews with plant managers indicate that companies involved in nuclear fuel production would probably not settle a class action case with the local community but would continue risk communication programs based on information dissemination and public involvement. A number of managers perceived the DOE settlement at Fernald to be a purely political gesture, one that has generally damaged the reputation of owners and operators of other nuclear facilities, both DOE and commercial, including Fernald itself.

\subsection{ANALYSIS OF RISK MANAGEMENT AND ACCEPTANCE}

The success with which commercial companies and DOE and its facility contractors manage risk and operate in a manner acceptable to local communities and states may depend closely on the nature of the information dissemination processes at nuclear facilities. Public trust, confidence, and perceptions of risk associated with nuclear facilities are closely related to measures taken by site operators and managers to reduce or compensate for risk or to provide better information that reduces the uncertainty about risk. This section reports on how individuals, groups, and state (gubernatorial and legislative) and local officials receive information about the nature of controversial facilities and the impact this process has had on perceptions of risk.

The levels of facility interaction with the community seem to be highly variable among sites; at DOE sites, in particular, interaction with the community is directed more 
toward financial commitments to educational and science programs in the local school system and other community support programs. At both DOE and commercial facilities, outreach programs are designed to raise awareness of the facilities themselves and of the scientific nature of activities taking place there as a means of increasing public trust and confidence in the facilities. With respect to DOE facilities, although the public has often been provided with the same amount of information about the environmental impact of on-site activities as has been provided for commercial facilities, the timing of information releases has, at some of the DOE facilities, been slower, with releases often requiring approval from DOE headquarters.

The poor quality and extent of monitoring, lack of timeliness in releasing information to the public, and delays experienced in implementing remedial action programs (when compared with these activities at commercial facilities) have tended to reduce acceptance of DOE facilities. These problems have been partly a result of the lack of a legal requirement to monitor emissions at DOE sites and partly a result of the insufficient availability of resources for adequate monitoring. The consequent pressure to provide full information on environmental impacts has, in itself, tended to raise the level of risk perceived. At the commercial facilities, the companies' experience with public relations activities at other manufacturing facilities seems to have prepared public relations officers to respond to community concerns in situations in which there have been problems at a plant.

In addition to local education and community support programs, public acceptance of the 11 nuclear facilities examined can also be attributed, in part, to the extent to which the facilities have developed economic ties with the local community. Although many of the community economies at the 11 sites were heavily dependent on the facilities for employment and income, in some cases, this dependence was insufficient to offset any adverse perceptions that had arisen. The commercial facilities seem better able to offset the potential for the development of adverse risk perceptions through economic diversification. The Lynchburg plant, for example, is perceived to be a low-risk facility despite (1) local demonstrations by antiwar groups, (2) dissension within the state toward the plant, (3) EPA oversight of the plant at the present time, and (4) the stigma associated with the plant as being the manufacturer of the Three Mile Island reactors. This perception seems to be held because the facility is important to the economy of the local community, both as an employer and as part of a company that has diversified its activities in the local area. The link between public trust and confidence and local economic diversification also seems apparent at the Wilmington and Windsor facilities. At many DOE sites, links to the local economy that extend beyond the direct contribution of the facility to local employment are marginal. The exception is in Miamisburg, where research scientists from the Mound facility have begun new businesses and are apparently willing to remain in the area despite the 1991 plan to close the facility.

Attempts to use public relations efforts to gain acceptance of the facilities in the community are more successful when the efforts are long term and honest. Trust in facility management is improved in particular when key management officials have spent time in the community and their level of participation in community activities has been high. At a 
number of DOE sites (Fernald in particular), DOE executive management has moved key managers to and from other DOE sites with some frequency. This movement makes it difficult for members of the local community and state officials to identify the personnel who are responsible for areas of facility operation that have been the subject of concern; this difficulty has tended to heighten perceptions of risk.

The problem of risk communication at DOE sites also seems to have been exaggerated by the nature of the relationship between DOE and its site contractors. Attempts by a contractor's public relations office to provide timely information to the public have often been slowed at some sites because information must go through a DOE approval process before it is released. At Fernald in the early and mid 1980 s, the time it took for the contractor (NLO) to obtain approval contributed significantly to the development of mistrust of DOE with respect to the true nature of events and releases at the facility. Because DOE has not until recently been legally required to allow other environmental agencies, such as state environmental protection agencies and the EPA, into its facilities, facility management has often blocked access to these agencies. This "closed door" policy has led to heightened risk perceptions in the community as information on environmental problems reaches local newspapers.

Changes in contractor at DOE sites have also led to problems for DOE in the local communities. Contractor changes may be presented as part of new efforts to monitor releases and disseminate information to the public. In many cases, however, a large proportion of the staff members employed by the previous contractor are rehired by the new contractor; thus, it has been alleged, many of the old attitudes toward risk management and community participation are left essentially unchanged. Contractor changes have taken place recently at Fernald (from NLO to Westinghouse, and now to Fluor Daniels) and Paducah (from Union Carbide to Martin Marietta).

The more successful attempts to mitigate concerns are those that rely on developing and maintaining two-way communication with local community groups and individuals, Active participation in public relations at public meetings clearly has more successful results than does mere attendance at meetings. An additional element in building the trust of the community is the credibility of information providers (e.g., facility public relations officers, DOE spokespersons, local officials, and environmental activists). Facility management that is both stable and trustworthy has been an important factor in determining the level of perceived risk in a community.

In cases where risk management policies have led to relatively low levels of acceptance in the local community, there may have been an exaggerated bias against DOE at nuclear facilities. In most of the cases examined, concern about the nature of environmental risk, a lack of reliable information, and generally poor public participation by plant management translated into opposition toward the facilities by community activists. In some cases, national antinuclear and environmentalist organizations had focused attention on problems at the facilities, but, in the majority of cases, concern had arisen from within the local community. Within the community, however, even if situations at the facilities were 
poor or deteriorating, the general level of concern did not match that of local activists. However, in cases where attempts to manage risk were poorest, such as at Fernald, the level of concern held by community groups seems to have been raised, so that their attitudes matched those of the citizen activist groups. 


\section{IMPACT OF ADVERSE PERCEPTIONS ON LOCAL ECONOMIC DEVELOPMENT}

\subsection{ANALYSIS OF SECONDARY DATA}

To provide a general impression of the impact of nuclear facilities on the economies of the regions surrounding the sites, this study examined employment data for the counties in which each facility is based. The results are shown in Appendix A. Each chart shows employment figures for six major sectors - agriculture, mining, construction, manufacturing, transportation and public utilities, and services - in each county over the period 1970 to 1989. Data for the figures were taken from the U.S. Department of Commerce publication County Business Patterns (1970-1989). Data at this level are used because the county is the smallest unit for which employment information is collected by federal statistical agencies. Vertical lines on the charts represent events at each facility that had the potential to produce adverse perceptions. Details on these events are included in Appendix B. Also included on each figure in Appendix A is a line for 1979 that represents the Three Mile Island accident and a line for 1986 that represents the Chernobyl accident.

Heightened fear of health effects can affect the level of employment in the local economy if manufacturing and service activities choose to relocate or at least curtail their activities in the area surrounding each facility. At a number of facilities, changes in risk perceptions might also affect the local tourist economy, if the number of visitors declines, or the agricultural economy, if consumers switch from locally grown produce because of a fear of contamination.

The figures show little or no correlation between the events at each facility that might contribute to the development of adverse risk perceptions and county employment trends. At the Erwin, Paducah, Portsmouth, and West Valley sites, changes in the scale of operations at the facilities seem to be reflected in the county manufacturing and employment totals. However, this correlation is almost certainly a result of the dominance of each facility in each of these counties rather than the emergence of secondary employment impacts as a result of adverse perceptions. At the other sites, there seems to be no relationship between perceptions of high risk at the nuclear facilities and local changes in employment.

An analysis of county employment data is only of limited application in analyzing the economic impact of changes in risk perceptions. This limitation is because a range of activities in addition to events associated with each facility may have affected employment gains and losses in the county as a whole. For example, Fernald is in Hamilton County, Ohio, which also contains metropolitan Cincinnati; the Mound facility is in Montgomery County, Ohio, which also contains the metropolitan area of Dayton. Both areas have experienced structural changes in employment throughout the $1970 \mathrm{~s}$ and $1980 \mathrm{~s}$. These changes, together with the overall level of employment in each sector, overwhelm any effects that might be associated with the two DOE facilities. Similar problems were also encountered in measuring impacts at the Wilmington and Windsor sites. A second problem with employment statistics is they measure only net changes in employment over time. 
Although there may have been substantial losses in employment in a particular county, as a result of changes in risk perceptions affecting business location decision making, for example, there may also have been gains in employment elsewhere in the county. This possibility makes it difficult to measure any changes in employment in specific business activities.

\subsection{CASE-STUDY FINDINGS}

Case studies indicate that perceptions of risk associated with nuclear facilities have an insignificant impact on local and regional economic development. Information on local impacts was taken from site reviews and interviews of local plant managers, key industry personnel, and local development authorities. This study examined current trends in business location and relocation decisions, the nature of employment and economic development being created and lost, and the sensitivity of business location decisions to actual and perceived changes in environmental quality stemming from each facility. The study also evaluated the effects of each facility on tourism and changes in the success of local farms and agribusinesses in marketing agricultural products from areas surrounding nuclear facilities.

In general terms, the economic characteristics of a facility's location contribute more to the type and level of economic activity being created and lost than does the reaction of individual businesses to facilities viewed as significant disamenities. As was discussed earlier, the economies of the areas in which the facilities are located are somewhat different. Of the five commercial facilities, the Lynchburg, Wilmington, and Windsor facilities are located in small urban centers, as is the DOE facility at Mound. The Fernald plant is located close to a small rural center but is also close to the outer suburbs of the Cincinnati metropolitan area. Four of the five DOE facilities and two of the commercial facilities are located in or close to fairly small rural towns some distance from large regional markets, and they have relatively undiversified economies. These differences alone have influenced the character of economic activities in the community and region surrounding each facility.

Of the sites located in rural areas, the economies in the areas surrounding the Erwin, Metropolis, Paducah, Portsmouth, and Weldon Spring facilities have similar characteristics in terms of structure and prospects for future economic development. Although there is some agricultural employment in each of these locations, agriculture has a smaller share of total employment in the local economies than do manufacturing and services. The facilities themselves either dominate local employment (Paducah and Portsmouth) or are significant local employers (Erwin and Metropolis). The Portsmouth location has a small amount of tourist activity based on its local heritage and a small retirement community. The Weldon Spring facility is surrounded by a wildlife refuge that has a small regional market. At each of these locations, this study found no evidence that either the presence of a nuclear facility or events that occurred during the lifetime of facility operations had a negative effect on the local economy or hindered economic development prospects. Despite the level of concern at Portsmouth and, to a lesser extent, at Paducah, the contribution each facility made to its local economy was perceived favorably. 
Although the Mound and Fernald sites are located in relatively small towns, both facilities are relatively close to regional metropolitan centers (Dayton and Cincinnati). The Mound facility in Miamisburg is on the periphery of suburban development outside Dayton, and the Fernald facility is likely to be reached by new suburban growth in the near future. In both locations, there is evidence of new development close to the site location: local roads are being upgraded around both facilities; regional distribution centers for a national chemical manufacturing company have been developed near Fernald; and shopping malls are being developed in the Miamisburg area.

A number of the nuclear facility sites are located in economies undergoing fairly rapid growth in certain manufacturing activities and in business and consumer services. The facilities at Lynchburg, Wilmington, and Windsor are located in areas with well-diversified, growing economies in which a fairly substantial number of new firms have chosen to locate. At Lynchburg, the traditional industries of paper milling, timber processing, and iron and steel foundries have been replaced by a number of light manufacturing industries; recently, General Electric and B\&W have added facilities to their operations. The services sector has also grown, with the development of two regional universities and a number of business service activities. The Windsor facility is within the growing metropolitan region of Hartford, close to the airport and major new industrial and transportation developments. At Wilmington, the economy grew rapidly in the 1980s; a variety of new light manufacturing industries came into the area immediately east of the General Electric plant. In addition, the extension of I-40, from Raleigh to Wilmington, runs close by the facility; this situation has led to the rapid buildup of local and regional shopping areas and residential and commercial development.

The Wilmington and West Valley sites are also close to rapidly growing tourist and recreational areas. At Wilmington, the area south of the city from Wrightsville to Cape Fear has become a popular retirement community, recreational area, and tourist destination. The city itself also has a number of historical features that have drawn tourists. The area close to the West Valley facility has become a popular ski resort, and a significant amount of new development has occurred in the adjacent town of Ellicotville in the last 10 years. New York State has heavily promoted the area as a recreational resource and has improved its connections to Buffalo and Erie. The area immediately surrounding the facility remains primarily agricultural and has not attracted any new tourist developments, but this lack is primarily because attractive local tourist centers already exist. No manufacturing or service activities appear to have been gained or lost as a result of events at the nuclear facility.

As the literature review revealed, although amenities may be important in decisions to site or relocate businesses or business activities, only businesses involved in a limited number of activities actually consider amenities in their location decisions, and these types of businesses may not be the ones that would choose locations like those in which nuclear facilities are located. Amenities seem to be considered primarily by firms that are large enough to choose separate locations for different functions and by a limited number of smaller manufacturing and business service firms. Corporate headquarters and other business functions requiring high-order executive and white-collar staffs (e.g., financial, insurance, and 
legal services; advertising; and research and development activities) are likely to make their primary consideration the need to minimize the costs of face-to-face contacts among clients, customers, and other staff; thus, they are likely to choose larger metropolitan areas and the urban amenities within them. Smaller firms that market specialized business services also often choose larger urban areas to be close to their major markets.

Smaller specialized business service firms (e.g., engineering, management, computer consulting, architectural, marketing, and financial service firms) might also locate in regional centers with improved mail and telecommunications services if they can benefit from national contact networks. It is unclear, however, how the cultural and recreational amenities (or simply the absence of disamenities) associated with smaller cities have influenced the location decisions of smaller producer service firms. Some firms may choose amenity-rich locations if those amenities attract specialized labor groups. Other firms may choose locations that have already attracted highly educated, mobile workers. In both cases, amenities may be an indirect influence on location. Newer business service firms may also be started by staff members who were originally employed by local firms, and local amenities may influence their decision on whether to remain in existing locations.

Amenities are much less likely to influence the location of manufacturing activities. Although there are a large number of manufacturing firms, manufacturing employment is concentrated in a relatively small number of large corporations. Within these firms, specialized production activities need to be located close to headquarters and research and development facilities that provide initial support. As production becomes routine and does not require substantial scientific and technical backup, it is located in more peripheral areas, where the cost and availability of production labor are the prime locational determinants. The same is true for routine back-office functions. Smaller manufacturing firms, on the other hand, may show slightly different locational patterns, with the individual preferences of the entrepreneur (particularly local knowledge of markets and suppliers and preference for a hometown location) being an important factor. In this case, the local cultural preferences of the entrepreneur or key staff rather than the absence of significant local disamenities may provide a basis for location decisions.

Given that many nuclear facilities examined are located in predominantly rural areas near small metropolitan areas, it is perhaps unsurprising that the impact of these facilities on business location and economic development has been limited. Because only a few industrial activities locating in these areas are likely to consider local disamenities in their location decision, it is not surprising that the importance of risk perceptions associated with the nuclear facilities was limited. 


\section{CONCLUSIONS AND RECOMMENDATIONS FOR PROGRAMS FOR SITING NUCLEAR FACILITIES}

On the basis of the case-study findings at the 11 nuclear facilities examined, a number of conclusions can be drawn and recommendations made. These may assist federal agencies in siting nuclear facilities. The findings will be useful not only in the successful siting of temporary and permanent nuclear waste facilities but also in redesignating existing nuclear energy production facilities as waste storage sites, as production operations at these facilities end. The findings on the formation, expression, and management of risk perceptions should also be useful when applied to nuclear waste transportation programs, as decision makers plan the most effective approaches for moving waste among remote locations.

\subsection{RELATIONSHIP BETWEEN FACILITIES AND THE PUBLIC}

The most significant finding of the case-study analysis for DOE siting programs is that the level and quality of a facility's participation with state and local environmental agencies, interest groups, and community activists directly affect the level of risk perceived by the community. This study found that the level and quality of interaction are influenced by a number of factors.

The first influencing factor is the nature of the facility's participation. The majority of the facilities examined have undertaken some form of public relations effort in the community, including involvement in local educational and science programs, community sports programs, and arts programs. These efforts seem to have been made at both DOE and commercial facilities. While the level of involvement in these programs seemed to be a little higher than average at the commercial facilities, it did not differ from the level of involvement often found in other manufacturing firms based in relatively small communities.

The major difference between the commercial and DOE facilities lies in the amount of information provided to the public about events inside the facility that either have or could cause contamination. Part of the reason there has been a generally poor track record at DOE facilities is that until recently there has not been a legal mandate for DOE (or the contractor) to either collect or release environmental information or to allow other state or federal agencies into these facilities to collect this information. At commercial facilities, however, companies are required to monitor operations under the 1970 Clean Air and Clean Water Acts and to allow the EPA and NRC to review safety procedures and the Office of Safety and Health Administration (OSHA) to investigate worker complaints. At DOE facilities, until recently, management policies have also allegedly differed with respect to the quality of voluntary monitoring undertaken and the timing of release of information and the content of that information in the event of contamination. These differences in the amount of public information released seem to be reflected in differences in the risk perceptions of the local communities and state agencies. One factor contributing to the perception problem at DOE facilities is the length of time facility officials have dealt with local and state agencies and other concerned groups. Many times, at both DOE and commercial facilities, management 
representatives have participated in community support programs since the facilities were originally sited. In contrast to the commercial facilities, however, DOE facilities have only recently routinely begun to proactively release information to the public. Also, at DOE facilities, personnel have frequently been moved to and from sites, which can make it difficult for local community groups to develop relationships with key officials to whom they can express their concerns.

A facility's early participation in the community would therefore seem to be of crucial importance in the development of a successful siting program. Participation that includes dialogue with local and state groups and agencies (and allows these agencies to monitor environmental quality and provide this information to the public) both before the facility is sited and throughout its lifetime also seems important.

The second important factor that can contribute to the development of successful relationships with the public is an interactive relationship with communities, agencies, and interest groups. Facilities that engage in two-way communication with the community and state seem to be more successful in producing public trust and confidence than those that engage in one-way communication. An important distinction must also be made between public relations and public information. At the DOE facilities, it has been problematic for managers to have an interactive relationship with the public because of the need to maintain secrecy because of the nature of the technology and materials being produced. When DOE and its contractors have responded to contamination problems and the consequent concerns of the community, however, these responses have often been inconsistent from facility to facility. On the other hand, the companies that operate commercial nuclear facilities have engaged in interactive communication and have been more successful in getting local communities to accept their facilities. In general, officials at commercial facilities have been more timely in their responses to community concerns, participated for longer periods in public information programs, maintained a more open approach to communities and state agencies, and remained at the facilities they represent longer than have officials in similar positions at DOE facilities.

\subsection{RELATIONSHIP BETWEEN FACILITIES AND LOCAL ECONOMIES}

The economic links of facilities with host communities are an important factor to consider in managing risk and promoting acceptance of the facilities. Economic links may be used to raise levels of acceptance of noxious facilities; in these cases, hosting communities receive benefits from the facility other than those resulting solely from the employment of local people at the plants. In addition to the employment links, a number of the facilities examined have procurement policies favoring local contractors and suppliers. These policies set up a series of multiplier effects in the local economy, in which employment and income are generated indirectly through the purchases made at each facility. There also seem to be differences among the facilities in terms of how the economic benefits are presented to the public. Managers at commercial facilities seem more successful in promoting the benefits of their facilities to the public than the managers at DOE facilities. The varying levels of acceptance of facilities seem to reflect these differences. 
Often links to the local economy may be presented by facility officials as being of considerable benefit to the local community. For these links to be significant, however, a substantial number of local suppliers of the more highly valued items used at each facility are needed. The rural nature of the majority of locations chosen for the facilities, however, has precluded the use of local suppliers for other than basic supplies and materials. Only two of the facilities examined (the commercial facility at Lynchburg and the DOE facility at Mound) have had significant links with the immediate local economy. At Lynchburg, stronger links had been fostered as a result of the diversification program undertaken in the area by $B \& W$ toward research and development of computer software, partly as a result of the partnership B\&W has with a French company. At the Mound facility, diversification at the facility itself - away from nuclear and into nonnuclear materials - has led to employment of a large number of scientific and technical staff on site, the majority of whom live close to the plant. In both of these communities, there seems to be a high level of acceptance of these facilities. Both these plants are in urban locations that provide an attractive environment to personnel coming from other locations, a stable and high-income base for the local community, and a supply of highly skilled labor (should new businesses choose to locate in the community) for new businesses.

These findings suggest that the siting of a nuclear facility is much more likely to be successful if links between the facility and the local community extend beyond the employment of production workers and the local purchase of basic materials and supplies. In a number of communities studied, these economic links to the community did not seem sufficient to offset perceptions of risk, although, in many cases, adverse perceptions seemed more likely to be expressed when the uncertainty associated with the future of a facility was greater. With respect to facilities likely to close, adverse perceptions could be reduced if local workers would be trained and employed in environmental remediation as cleanup operations begin. With respect to new nuclear facilities, the most promising direction for siting programs seems to be to search for new locations in smaller urban centers. In these centers, additional economic activity might be developed, either as a direct result of the activities at the facility itself or as an indirect result of local businesses making use of the specialized skills developed at the nuclear facilities. Additional activity might be encouraged by the company or operating agency, through colocating other activities or through attracting new businesses that could take advantage of pools of specialized local labor developed as a result of nuclear-related activities. In addition, amenities in these centers are often attractive to individuals with scientific and technical expertise, if there are sufficient local employment opportunities. Once individuals with these skills are established in the local area, their skills might also be used by local firms or other businesses attracted to the area.

Both the colocation of additional facilities by the company or operating agency and the development of new business activities in the local economy through the market for specialized labor would help economies surrounding nuclear facilities become more diversified and conceivably reduce the likelihood of adverse perceptions of risk. In general, however, businesses involved in only a limited number of activities are likely to choose locations close to nuclear facilities. The reason is not because of adverse perceptions of risk but because only a limited number of business activities are likely to be profitable if operated in these 
locations. Firms that are less sensitive to local economic conditions and that might consider amenities in their location decision are likely to prefer the amenities found in larger urban centers over the amenities present in the predominantly rural locations hosting nuclear facilities. In general, the success of any program that attempts to limit the development of risk perceptions by enhancing the economic links between nuclear facilities and local communities is likely to be limited by the locational preferences of businesses. 


\section{REFERENCES}

Allison, G., 1971, Essence of Decision: Explaining the Cuban Missile Crisis, Little, Brown, \& Co., Boston, Mass.

Allison, T., 1991, unpublished information, Argonne National Laboratory, Argonne, Ill.

Allison, T., and F.J. Calzonetti, 1990, The Role of Amenities and Other Factors in Influencing the Location of Nonmanufacturing Industry in the United States, report ANL/EAIS/TM-41, Argonne National Laboratory, Argonne, Ill., July.

Arnstein, S., 1969, "A Ladder of Citizen Participation," Journal of the American Institute of Planners 35:216-224, July 4.

Ballard, S.C., and T.E. James (editors), 1983, The Future of the Sunbelt, Praeger, New York, N.Y.

Barlett, G.S., 1982, "Reactions of Adolescents to the Three Mile Island Plant Accident," in Chemical and Radiation Hazards to Children: Report of the 84th Ross Conference in Pediatric Research, L. Finberg (editor), Ross Laboratories, Columbus, Ohio, pp. 96-115.

Bromet, E., 1980, Three Mile Island: Mental Health Findings, Western Psychiatric Institute and Clinic and the University of Pittsburgh, Pittsburgh, Penn.

Burgess, J.A., 1982, "Selling Places: Environmental Images for the Executive," Regional Studies 16:1-17.

Burns, L., and W.N. Pang, 1977, "Big Business in the Big City: Corporate Headquarters and the CBD," Urban Affairs Quarterly 12:533-544.

Calzonetti, F.J., and T. Allison, 1992, unpublished information, Argonne National Laboratory, Argonne, Ill.

Carson, R., 1962, Silent Spring, Houghton-Mifflin, Boston, Mass.

Center for Survey Research, 1988, National Telephone Survey of Nuclear Waste Issues, prepared for Nevada Agency for Nuclear Projects/Nuclear Waste Project Office, Carson City, Nev.

Clark, D.E., 1991, personal communication, Marquette University, Milwaukee, Wisc., Aug.

Clark, W., 1980, "Witches, Floods and Wonder Drugs: Historical Perspectives on Risk Management," in Societal Risk Assessment: How Safe Is Safe Enough?, R.C. Schwing and W.A. Albers, Jr. (editors), Plenum Press, Inc., New York, N.Y., pp. 287-313. 
Clarke, L., 1988, "Explaining Choices among Technological Risks," Social Problems 35 (1):501514.

Clarke, L., 1989, Acceptable Risk: Making Decisions in a Toxic Environment, University of California Press, Berkeley, Calif.

Cole, G.A., and S.B. Withey, 1981, "Perspectives on Risk Perceptions," Risk Analysis 1:143163.

Combs, B., and P. Slovic, 1979, "Newspaper Coverage of Causes of Death," Journalism Quarterly 56:837-849, winter.

Commoner, B., 1985, "Economic Growth and Environmental Quality: How to Have Both," Social Policy, pp. 18-26, summer.

Covello, V.T., et al., 1982, "Risk Analysis, Philosophy and the Social and Behavioral Sciences," Risk Analysis 2:53-58.

Decision Research and Mountain West Research, 1989, Perceived Risk, Stigma, and Potential Economic Impacts of a High-Level Nuclear Waste Repository in Nevada, report NWPO-SE-023-89, prepared for Nevada Agency for Nuclear Projects/Nuclear Waste Project Office, Carson City, Nev.

Douglas, M., and A. Wildavsky, 1982, Risk and Culture: The Selection of Technical and Environmental Dangers, University of California Press, Berkeley, Calif.

Downey, G.L., 1985, "Federalism and Nuclear Waste Disposal: The Struggle over Decisionmaking," Journal of Policy Analysis and Management 5(1):73-99.

Einhorn, H.J., and R.M. Hogarth, 1981, "Behavioral Decision Theory: Processes of Judgment and Choice," Annual Review of Psychology 32:53-88.

Fischhoff, B., 1977, "Cost-Benefit Analysis and the Art of Motorcycle Maintenance," Policy Sciences 8:177-202.

Fischhoff, B., et al., 1978, "How Safe Is Safe Enough: A Psychometric Study of Attitudes toward Technological Risks and Benefits," Policy Sciences 9:127-152.

Fischhoff, B., et al., 1981, Acceptable Risk, Cambridge University Press, Cambridge, Great Britain.

Fox, W.F., et al., 1985, An Economic Analysis of a Monitored Retrievable Storage Site for Tennessee, University of Tennessee, Center for Business and Economic Research, Knoxville, Tenn.

Freudenberg, N., 1984a, Not in Our Backyards! Community Action for Health and the Environment, Monthly Review Press, New York, N.Y. 
Freudenberg, N., 1984b, "Citizen Action for Environmental Health: Report on a Survey of Community Organizations," American Journal of Public Health 74(5):444-448.

Freudenberg, W.R., 1988, "Perceived Risk, Real Risk: Social Science and the Art of Probabilistic Risk Assessment," Science 242:44-49, Oct. 7.

Freudenberg, W.R., and R.K. Baxter, 1984, "Host Community Attitudes toward Nuclear Plants: A Reassessment," Social Science Quarterly 65(4):1129-1136, Dec.

Gamson, W.A., and A. Modigliani, 1989, "Media Discourse and Public Opinion on Nuclear Power: A Constructionist Approach," American Journal of Sociology 95:1-37, July.

George, D.L., and P.L. Southwell, 1986, "Opinion on the Diablo Canyon Nuclear Power Plant," Social Science Quarterly 64(4):722-735.

Hall, P., et al., 1987, Western Sunrise: The Genesis and Growth of Britain's Major High-Tech Corridor, Allen Unwin, Boston, Mass.

Hattis, D., and D. Kennedy, 1986, "Assessing Risks from Health Hazards: An Imperfect Science," Technology Review, pp. 60-71, May/June.

Hohenemser, C., et al., 1983, "The Nature of Technological Hazard," Science 220:378-384, April 22.

Houts, P., et al., 1980, "Extent and Duration of Psychological Distress of Persons in the Vicinity of Three Mile Island," in Proceedings of the Pennsylvania Academy of Science Annual Meeting, 54:22-28.

Hunter, S. (West Virginia University, Morgantown, W.V.), 1992, "Ontology, Perceptions of Risk, and Citizen Participation: Variables Affecting Attitudes on Environmental Issues," presented at the International Studies Association Annual Conference, held in Atlanta, Ga., in April.

Ihlanfeldt, K., and M. Raper, 1990, "The Intrametropolitan Location of New Office Firms," Land Economics 66:182-198.

Inglehart, R., 1977, The Silent Revolution, Princeton University Press, Princeton, N.J.

Inglehart, R., 1988, "The Renaissance of Political Culture," American Political Science Review 82:1297, Dec.

Inglehart, R., 1990, Culture Shift in Advance Industrial Society, Princeton University Press, Princeton, N.J.

Jacob, G., 1990, Site Unseen: The Politics of Siting a Nuclear Waste Repository, The University of Pittsburgh Press, Pittsburgh, Penn. 
Kahneman, D., et al. (editors), 1982, Judgment under Uncertainty: Heuristics and Biases, Cambridge University Press, Cambridge, Great Britain.

Kale, S.R., and R.E. Lonsdale, 1979, "Factors Encouraging and Discouraging the Location of Industries in Non-Metropolitan Areas," in Non-Metropolitan Industrialization, R.E. Lonsdale and H.L. Seyler (editors), John Wiley \& Sons, Inc., New York, N.Y.

Kasl, S.V., et al., 1981, "The Impact of the Accident at Three Mile Island on the Behavior and Well-Being of Nuclear Workers: Job Tension, Psychophysiological Symptoms and Indexes of Stress," American Journal of Public Health 71:484-495.

Kates, R.W., 1977, "Assessing the Assessors: The Art and Ideology of Risk Assessment," Ambio 6(5):247-252.

Keeble, D.E., 1980, "Industrial Decline, Regional Policy and the Urban-Rural Manufacturing Shift in the U.K.," Environment and Planning A 12:954-962.

Keeble, D.E., 1989, "High-Technology Industry and Regional Development in Britain: The Case of the Cambridge Phenomenon," Environment and Planning C 7:153-172.

Kelley, P., 1991, personal communication, Fernald Environmental Management Project, Fernald, Ohio, Nov.

Kosmider, M., 1992, personal communication, Allied-Signal, Metropolis, Ill., Sept.

Kraft, M.E., 1982, "The Use of Risk Analysis in Federal Regulatory Agencies: An Exploration," Policy Studies Review 1(4):666-675, May.

Kraft, M.E., 1987, "Managing Technological Risks in a Democratic Polity: Citizen Participation and Nuclear Waste Disposal," presented at the National Conference of the American Society for Public Administration, held in Boston, Mass., March 28-April 1.

Kramer, B., and R.S. Moyer (editors), 1990, Nuclear Psychology Bibliography, The Society for the Psychological Study of Social Issues.

Lave, L., 1984, "Regulating Risks," Risk Analysis 4(2):79-80.

Lawler, J.J., and W. Parle, 1988, "Risk Communication and the NIMBY Syndrome in Hazardous Waste Decision-Making: Reconciling Technical Opinion and Citizen Participation," presented at Western Political Science Association Conference, held in San Francisco, Calif,, on March 10-12.

Levine, A., 1982, Love Canal: Science, Politics, and People, Lexington Books, Lexington, Mass.

Ley, D., 1985, "Downtown or Suburbs? A Comparative Study of Two Vancouver Head Offices," The Canadian Geographer 29:30-43. 
Malecki, E., 1989, "What about People in High Technology? Some Research and Policy Considerations," Growth and Change 20:67-79.

Markusen, A., et al., 1986, High-Tech America, Allen Unwin, Boston, Mass.

Mazur, A., 1975, "Opposition to Technological Innovation," Minerva 13(1):58-81.

McCabe, A.S., and M.R. Fitzgerald, 1988, "Open Decision Making and Citizen Participation in Environmental Policy: The DOE Attempt to Site a Nuclear Waste Facility in Tennessee," presented at the Southern Political Science Association Annual Conference, held in Charlotte, N.C., in Nov.

McGregor, B.D., et al., 1986, "The Development of High Technology in the Newbury District," Regional Studies 20:433-448.

Meyer, M.W., and K. Solomon, 1984, "Risk Management in Local Communities," Policy Sciences 16:245-265.

Moss, M., and A. Dunau, 1986, The Location of the Back Offices: Emerging Trends and Development Patterns, New York University, School of Continuing Education, Sylvan Lawrence Research and Data Center, New York, N.Y.

Nader, R., 1965, Unsafe at Any Speed, Bantam Books, New York, N.Y.

Nelkin, D., 1981, "Some Social and Political Dimensions of Nuclear Power: Examples from Three Mile Island," American Political Science Review 75:132-145, March.

Nelkin, D., 1984, "Science, Technology, and Political Conflict: Analyzing the Issues," in Controversy: Politics of Technical Decisions, 2nd ed., D. Nelkin (editor), Sage Publications, Beverly Hills, Calif., pp. 9-24.

Otway, H., 1987, "Experts, Risk Communication and Democracy," Risk Analysis 7(2):125-129.

Otway, H., and K. Thomas, 1982, "Reflections on Risk Perception and Policy," Risk Analysis 2:69-82.

Pacione, M., 1982, "Space Preferences, Locational Decisions, and the Dispersal of Civil Servants from London," Environment and Planning A 14:323-333.

Perrow, C., 1984, Normal Accidents: Living with High-Risk Technologies, Basic Books, Inc., New York, N.Y.

Pilisuk, M., et al., 1984, "Public Perception of Technological Risk," The Social Science Journal 24(4):403-413.

Plaut, T.R., and J.E. Pluta, 1983, "Business Climate, Taxes and Expenditures and State Industrial Growth in the U.S.," Southern Economic Journal 50:99-119. 
Pollock, P.H., et al., 1992, "Who Says It's Risky Business? Public Attitudes toward Hazardous Waste Facility Siting," Polity 24(3):499-513, spring.

Press, F., 1986, "Speaking about Risk," Chemtech 16(6):336-338, June.

Raiffa, H., 1970, Decision Analysis, Addison-Wesley, Reading, Mass.

Raiffa, H., 1984, "Concluding Remarks," in Societal Risk Assessment: How Safe Is Safe Enough?, R.C. Schwing and W.A. Albers, Jr. (editors), Plenum Press, New York, N.Y., pp. 339-341.

Raitz, K., 1988, "Advantages of Place as Perceived by Sunbelt Promoters," Growth and Change 19:14-29.

Rhodes, J., and A. Kan, 1971, Office Dispersal and Regional Policy, Cambridge University Press, Cambridge, Great Britain.

Rothman, S., and S.R. Lichter, 1987, "Elite Ideology and Risk Perception in Nuclear Energy Policy," American Political Science Review 81:381-404, June.

Ruckelshaus, W., 1983, "Science, Risk and Public Policy," Science 221:54-59, Sept. 9.

Schmenner, R.W., 1982, Making Business Location Decisions, Prentice Hall, Inc., Englewood Cliffs, N.J.

Schwebel, M., and B. Schwebel, 1982, "Children's Reactions to the Threat of Nuclear Plant Accidents," Annual Progress in Child Psychiatry and Child Development, pp. 371-383.

Schwing, R.C., and W.A. Albers, Jr. (editors), 1980, Societal Risk Assessment: How Safe Is Safe Enough?, Plenum Press, New York, N.Y.

Short, J.F., 1984, "The Social Fabric at Risk," American Sociological Review 49:711-725, Dec.

Silbergeld, E., 1987, "From the Outside: An Environmentalist's View," EPA Journal 13(9):34-35, Nov.

Slovic, P., et al., 1979, "Rating the Risks: The Structure of Expert and Lay Perceptions," Environment 21(3):14-39.

Slovic, P., et al., 1982a, "Facts Versus Fears: Understanding Perceived Risk," Judgment under Uncertainty: Heuristics and Biases, D. Kahneman et al. (editors), Cambridge University Press, Cambridge, Great Britain.

Slovic, P., et al., 1982b, "Why Study Risk Perception?" Risk Analysis 2:83-93.

Slovic, P., et al., 1991, "Perceived Risk, Trust, and the Politics of Nuclear Waste," Science 254(5038):1603-1607, Dec. 13. 
Smith, D., 1971, Industrial Location, John Wiley \& Sons, Inc., New York, N.Y.

Smith, J., 1981, "Attitudes toward Civil Defense and the Psychological Effects of Nuclear War," British Medical Journal 282(6297):963-965.

Smith, V.K., and F.R. Johnson, 1988, "How Do Risk Perceptions Respond to Information?", Review of Economics and Statistics 70:1-8, May.

Solantus, T., and M. Rimpels, 1986, "Mental Health and the Threat of Nuclear War - A Suitable Case for Treatment?", International Journal of Mental Health 15:261-275.

Spooner, D., 1973, "Industrial Movement and the Rural Periphery: The Case of Devon and Cornwall," Regional Studies 6:197-215.

Stafford, H, 1974, "The Anatomy of the Location Decision: Content Analysis of Case Studies," in Spatial Perspectives on Industrial Organization and Decision Making, F.E.I. Hamilton (editor), John Wiley \& Sons, Inc., New York, N.Y.

Thomas, L., 1986, "We Must Talk about Risk," Chemtech 16(5):262-263, May.

Tversky, A., and D. Kahneman, 1971, "Belief in the Law of Small Numbers," Psychological Bulletin 76(2):105-110.

U.S. Department of Commerce, 1970 through 1989, County Business Patterns, Washington, D.C.

U.S. Environmental Protection Agency, 1986, Guidance on Public Involvement in the RCRA Permitting Program, Office of Solid Waste, Washington, D.C., Jan.

Upton, A.C., 1981, "Health Impact of the Three Mile Island Accident," Annals of the New York Academy of Science 365:63-75.

Von Greyerz, W., 1962, Psychology of Survival: Human Reactions to the Catastrophe of War, Elsevier, New York, N.Y.

Wagner, R.V., 1985, "Psychology and the Threat of Nuclear War," American Psychologist 40:531-535.

Wattier D., 1992, personal communication, Paducah Gaseous Diffusion Plant, Paducah, Ky., Sept.

Weenig, M., and W.H. Midden, 1991, "Communication Network Influences on Information Diffusion and Persuasion," Journal of Personality and Social Psychology 61:734-742.

Wheat, L.F., 1973, Regional Growth and Industrial Location, Lexington Books, Lexington, Mass. 
Wheat, L.F., 1986, "The Determinants of 1963-77 Regional Manufacturing Growth: Why the South and West Grow," Journal of Regional Science 26:635-658.

Wildavsky, A., 1979, "No Risk Is the Highest Risk of All," American Scientist 67:32-37.

Wildavsky, A., 1987, Searching for Safety, Transaction, Inc., New Brunswick, N.J.

Wildavsky, A., and K. Dake, 1990, "Theories of Risk Perception," Daedalus: Journal of the American Academy of Arts and Sciences, pp. 41-60, fall.

Winner, L., 1985, The Whale and the Reactor, University of Chicago Press, Chicago, Ill. 
APPENDIX A:

TRENDS IN EMPLOYMENT AT NUCLEAR FACILITIES 


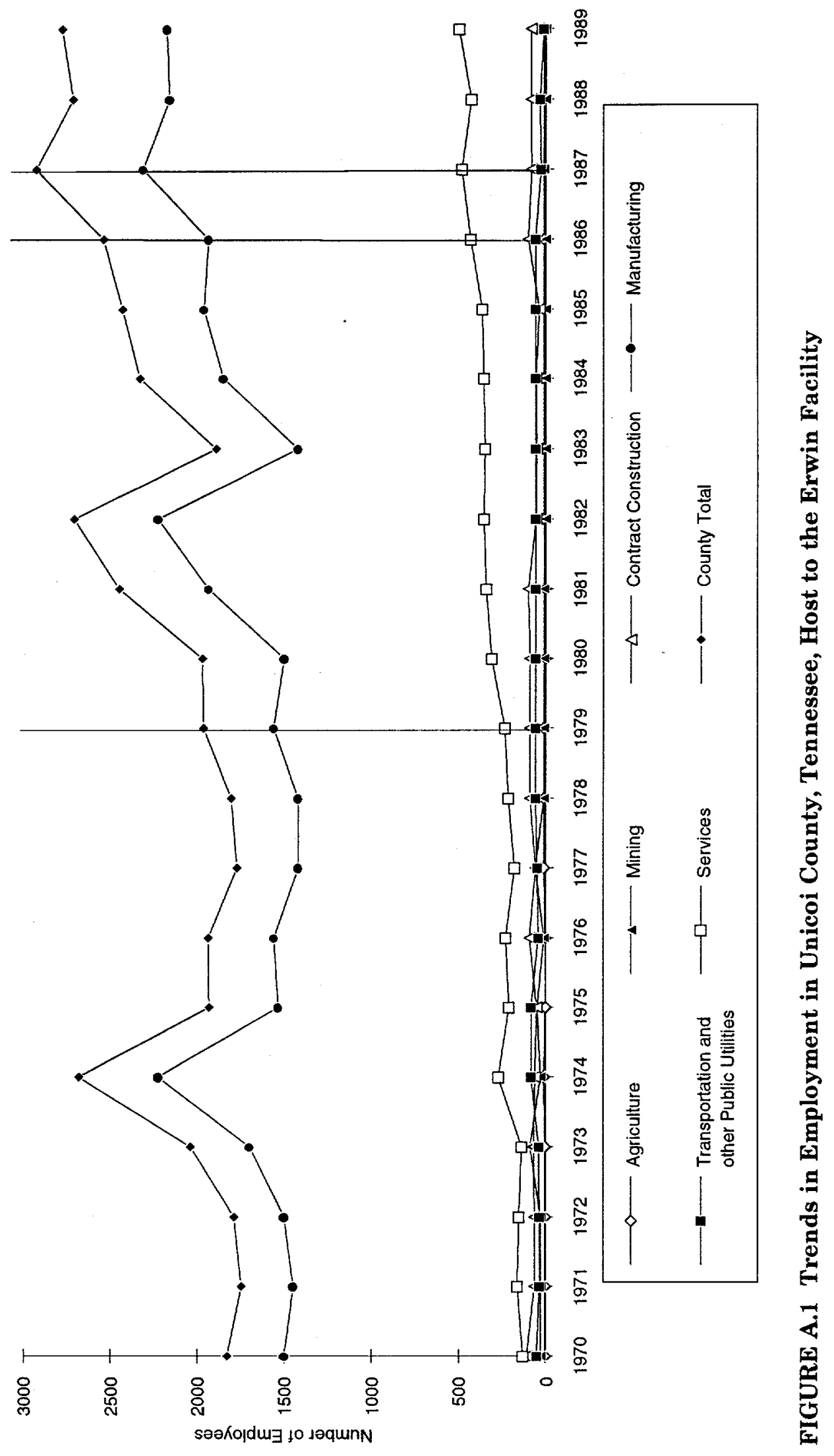




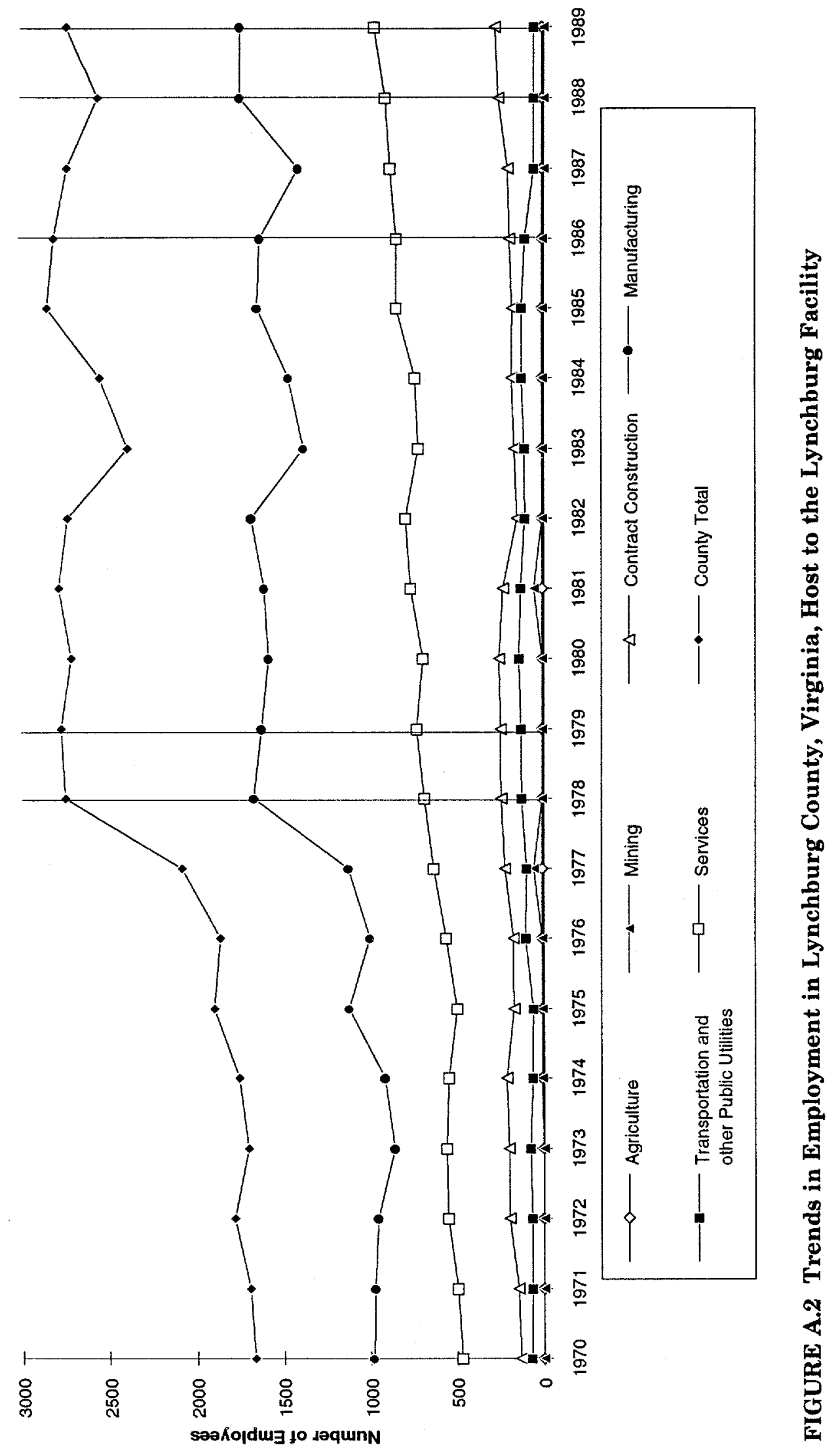




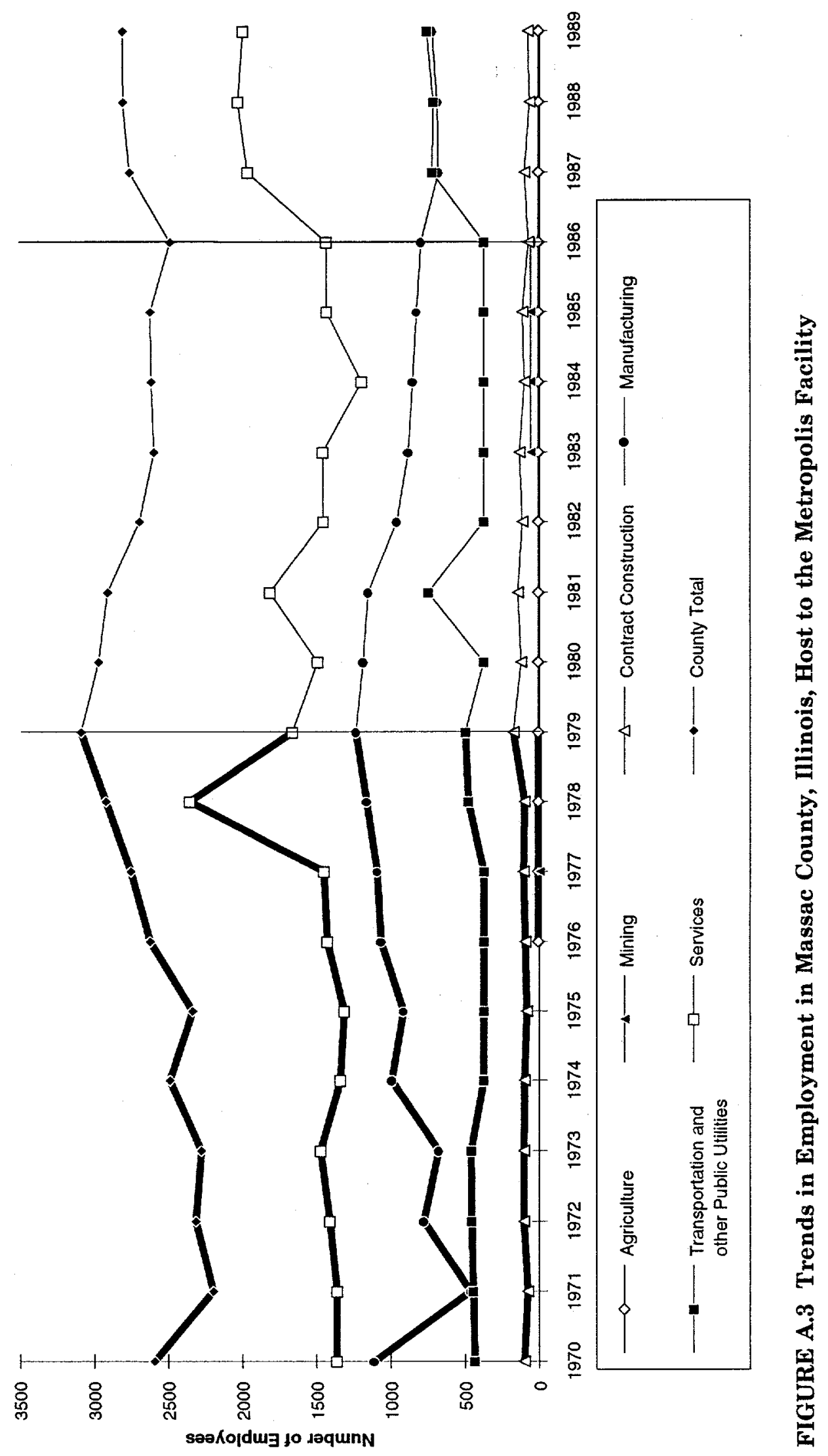




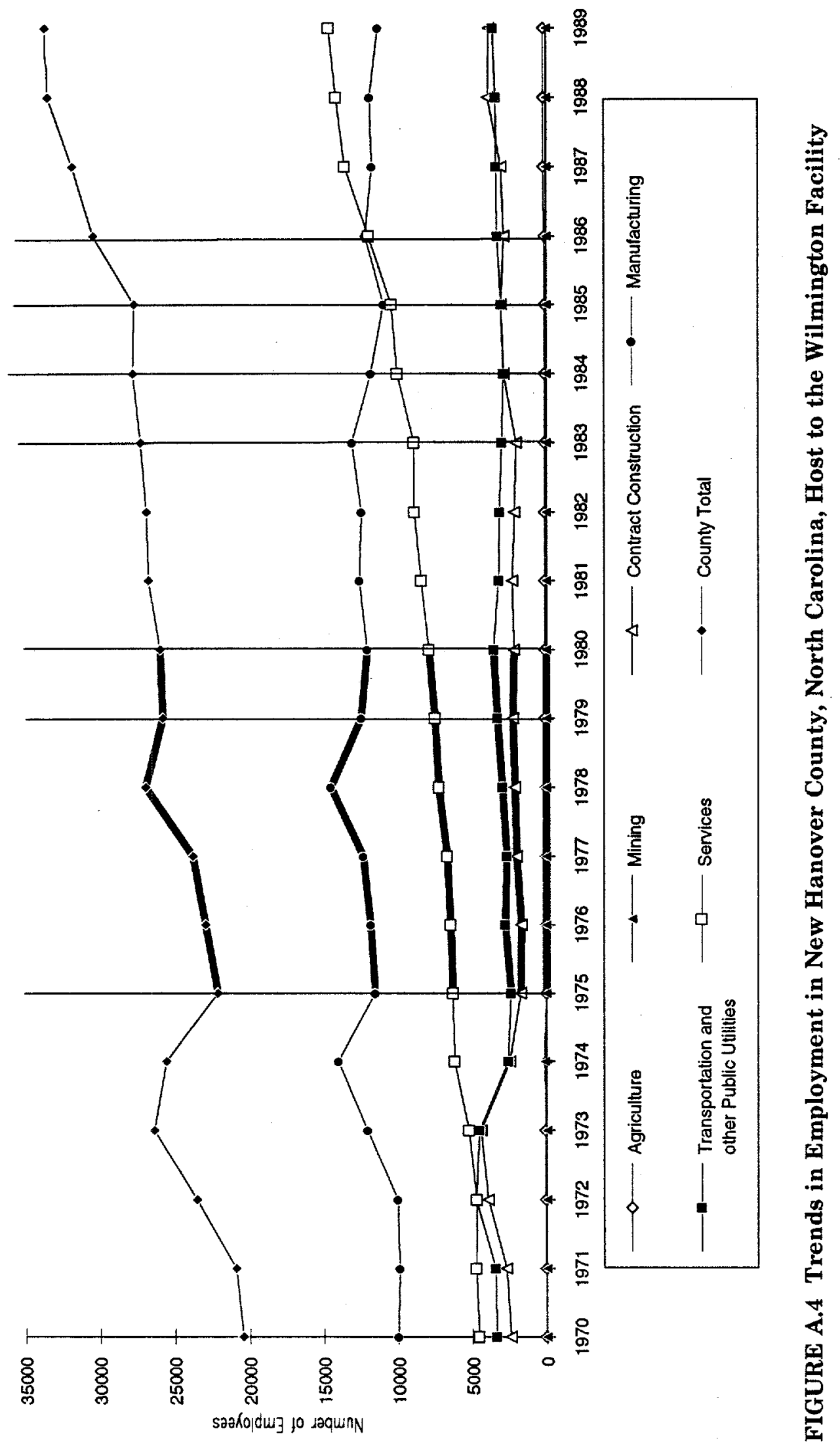




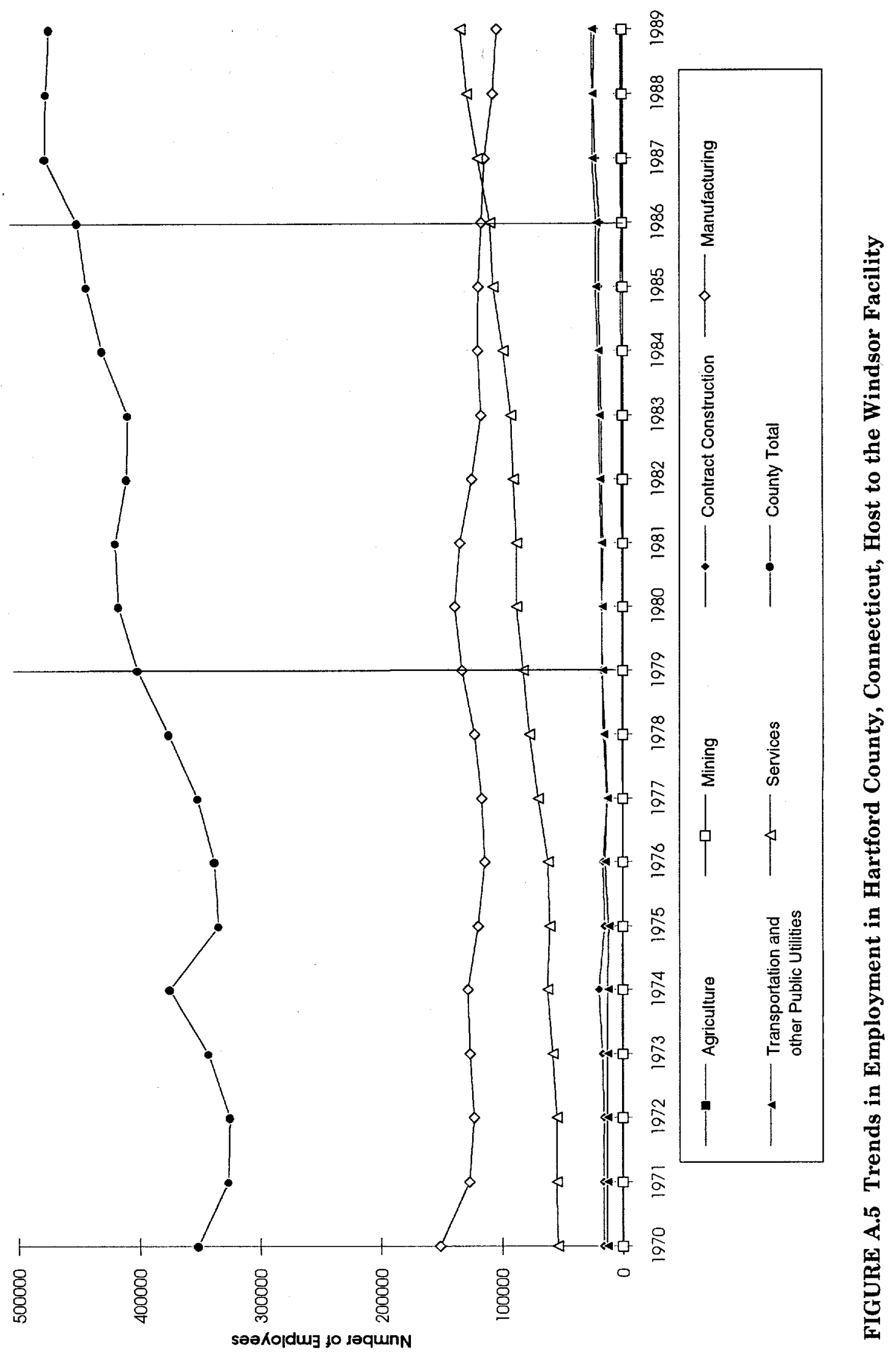




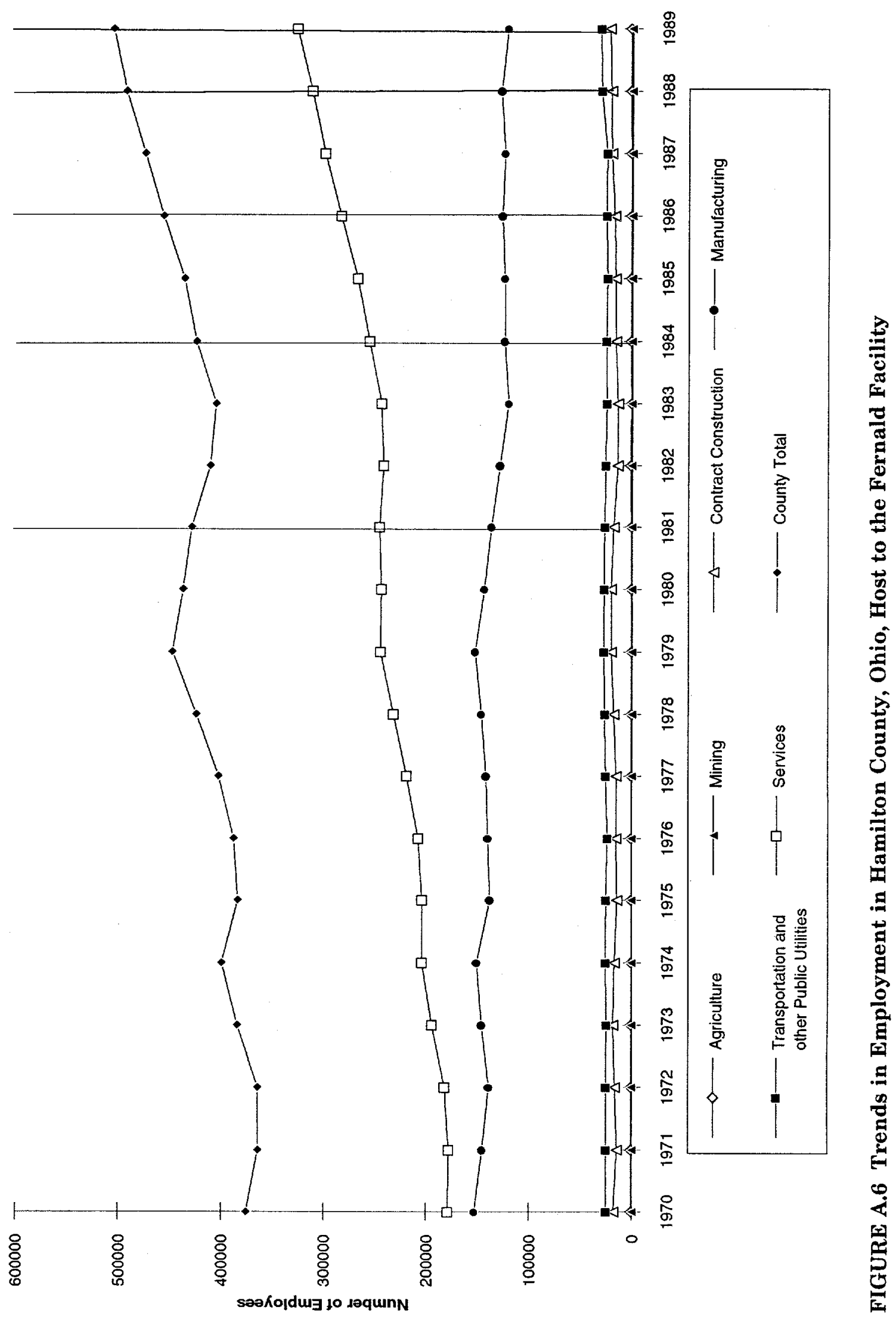




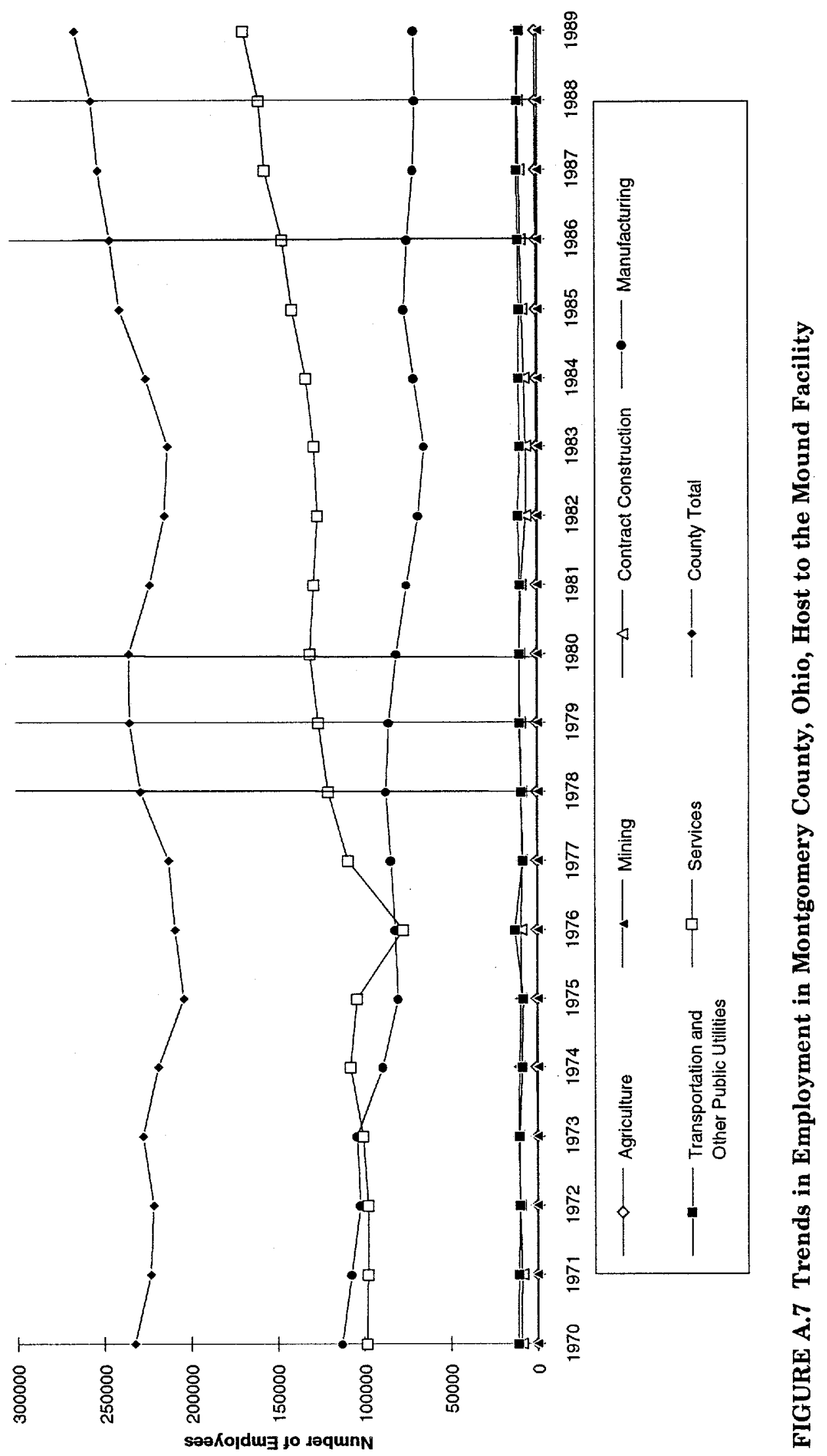




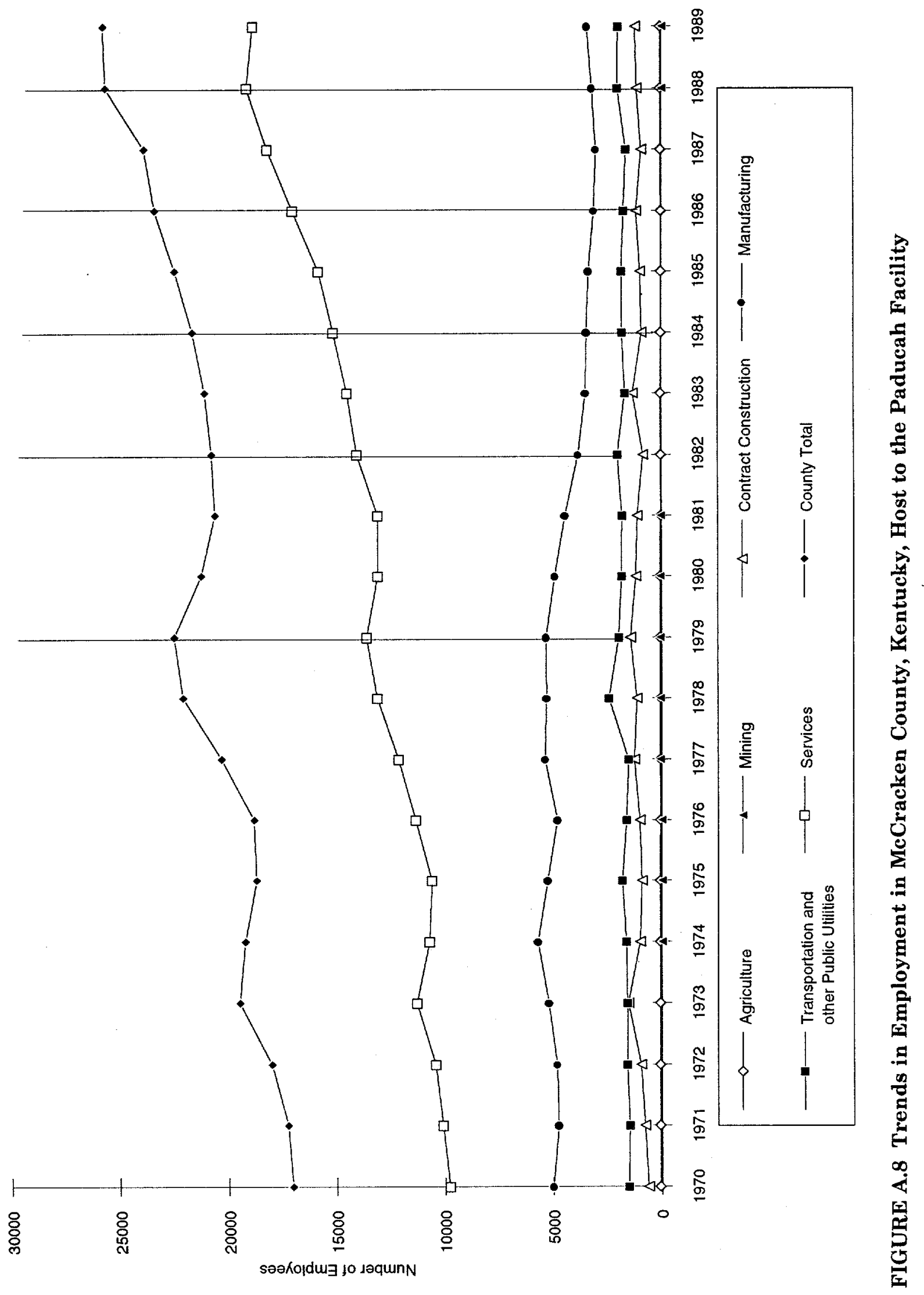




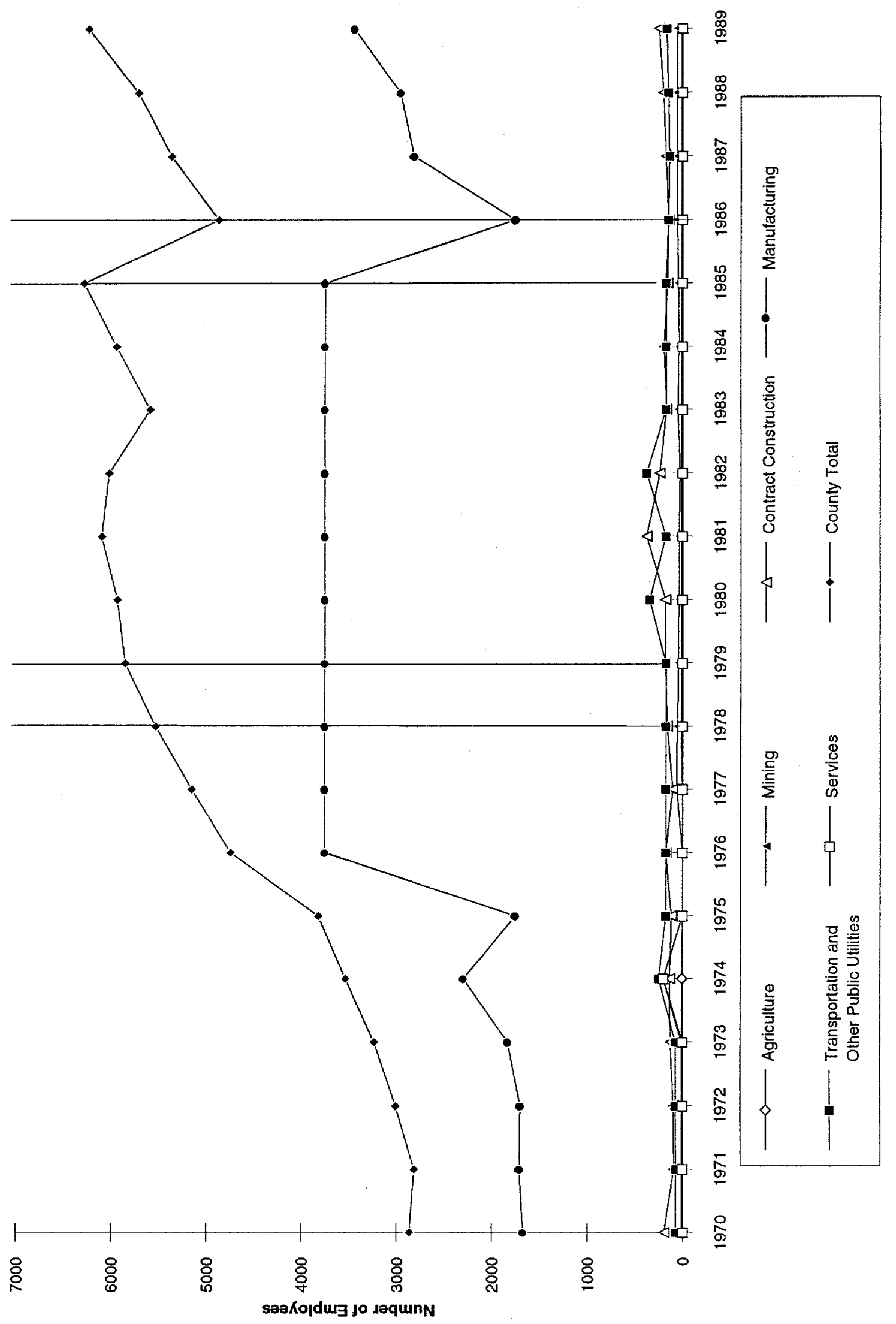

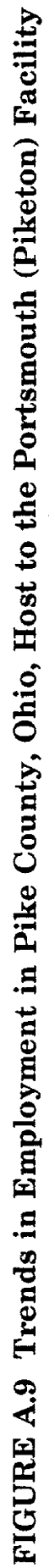




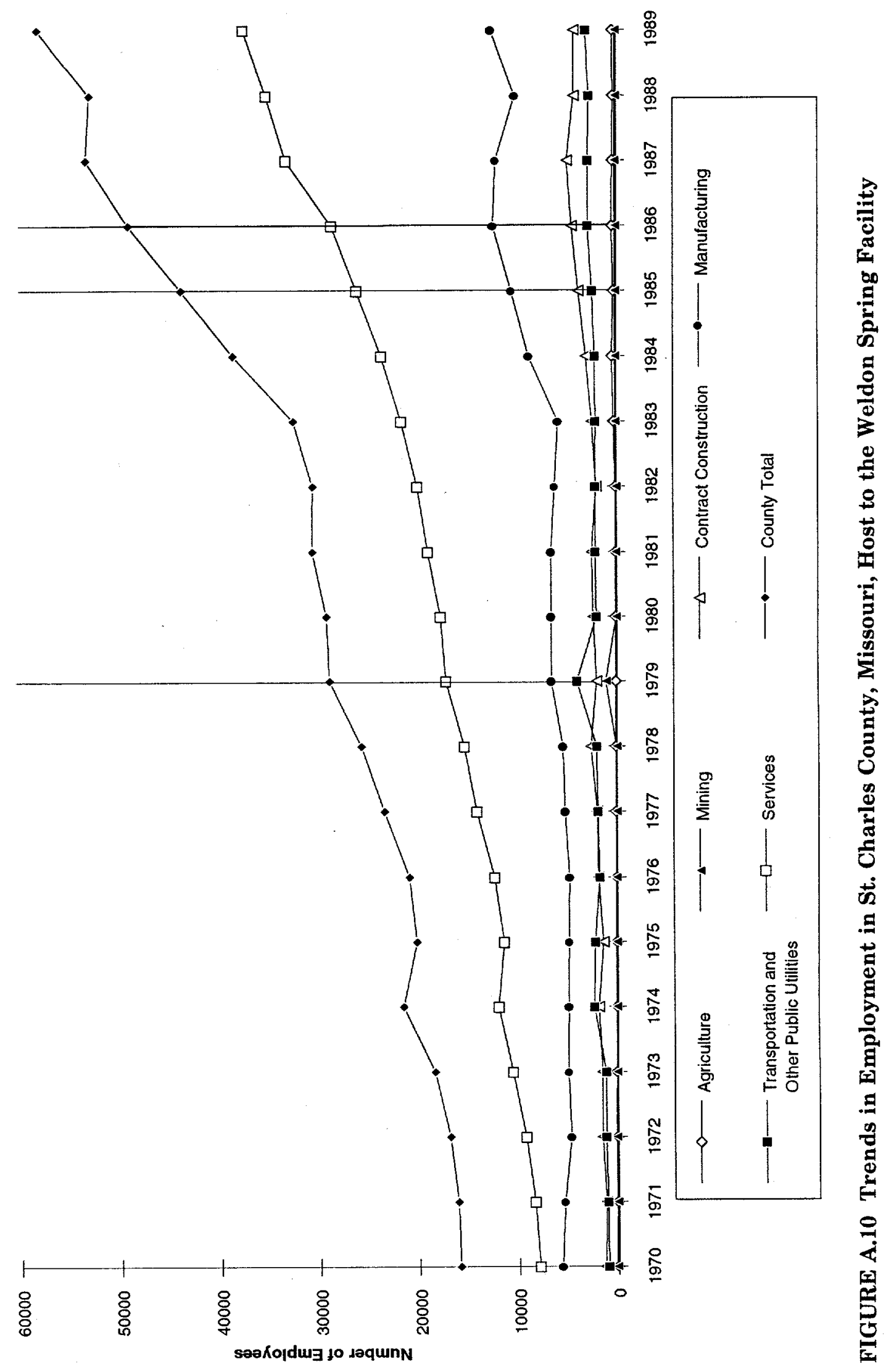




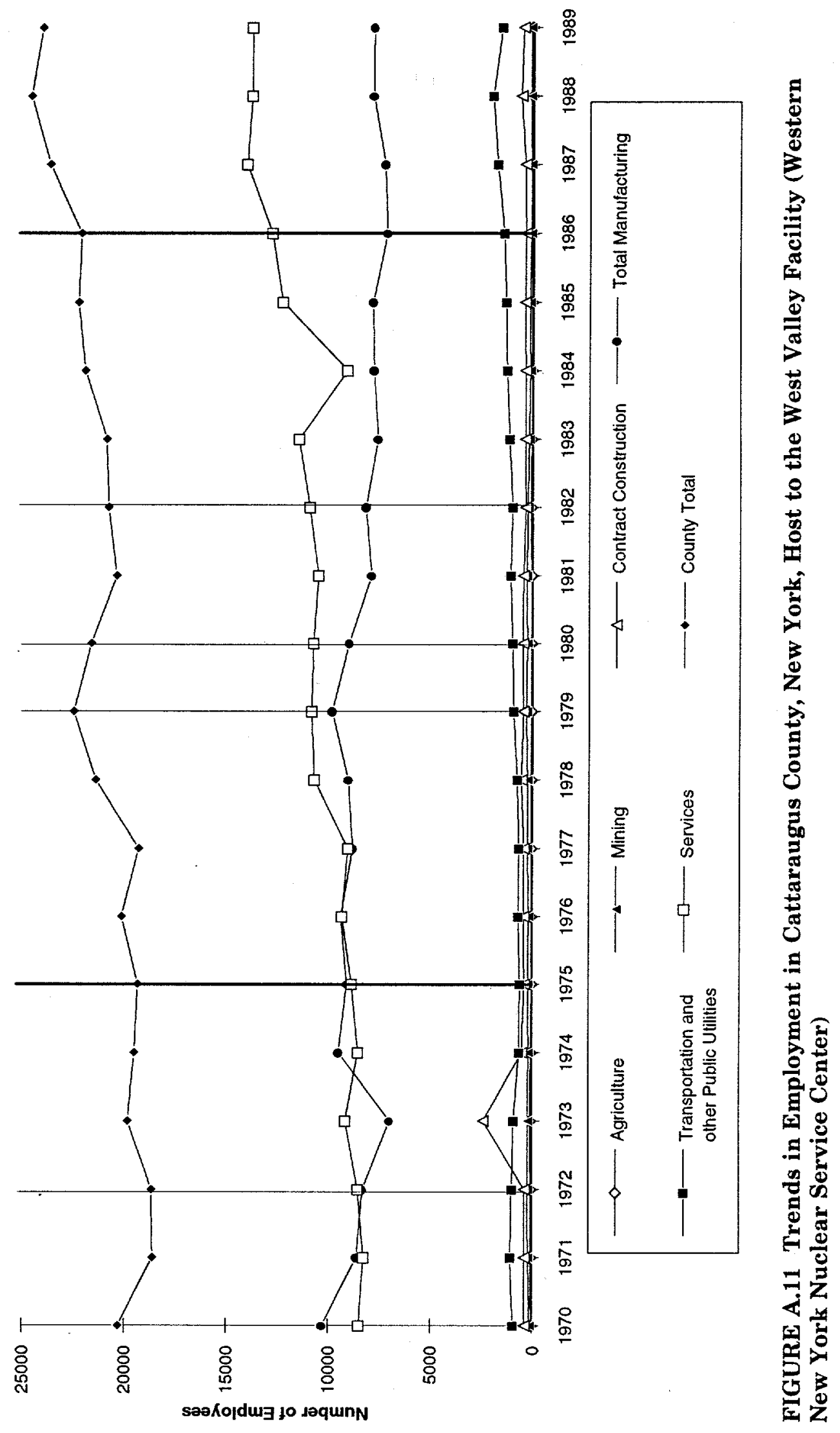


APPENDIX B:

IMPORTANT EVENTS AT CASE-STUDY FACILITIES: $1970-1989$ 


\section{APPENDIX B:}

IMPORTANT EVENTS AT CASE-STUDY FACILITIES: $1970-1989$

Facility and Year

Event

\section{Commercial Facilities}

Erwin, Tennessee

1979

1986

1987

Loss of 20 pounds of plutonium made national news.

Oil, gas, and atomic workers claimed health problems in a National Institute for Occupational Safety and Health study.

Nuclear Fuel Services took over facility.

Lynchburg, Virginia

Babcock and Wilcox was acquired by McDermott, Inc.

1988

Terrorist threats led to increased security.

1989

B\&W Nuclear Services/Framtome joint services company was formed.

Metropolis, Illinois

1970-1979 The facility expanded.

Wilmington, North Carolina

1975-1980 Layoffs occurred at the nuclear fuels facility.

1979

1980

Canisters containing uranium dioxide were stolen.

1980

Manufacture of reactor parts was suspended.

1983

Engine manufacturing plant was colocated at facility.

1984

Fuel rod manufacturing facilities were upgraded.

Whistleblower accused GE of ignoring safety standards.

1985

NRC was critical of GE's "production-minded attitude."

Windsor, Connecticut

No significant events have occurred to produce adverse perceptions. 
Facility and Year

Event

\section{U.S. Department of Energy Facilities}

Fernald, Ohio

1981 U.S. Geological Survey water survey found contamination in three off-

1984

1986

1988

1989

1989

1992 site wells.

Federal court ruled that nuclear facilities had to comply with federal pollution standards.

State of Ohio filed suit against DOE for violation of water statutes. Lawsuit was settled by DOE for $\$ 78$ million.

All production ceased.

Westinghouse took over the facility.

Fluor Daniels became the new contractor.

Mound, Ohio

1978

1980

1988

1990

1990

Continual monitoring of water emissions began.

Production of nonnuclear weapons began.

EG\&G took over as contractor.

National Cancer Institute study found area to be healthier than average.

U.S. EPA agreed on cleanup of Superfund site at the plant.

Paducah, Kentucky

1982

1984

1986

The plant was renovated.

Martin Marietta took over as contractor.

Environmental Advisory Committee was established.

1988

Water contamination was found in six off-site wells.

Portsmouth, Ohio

1978

1985

U-238 was spilled into on-site surface drainage streams.

Independent Advisory Committee was formed.

Weldon Spring, Missouri

Facility was abandoned.

1985

Site was designated as a high-priority Superfund site.

1986

DOE assumed responsibility for the site.

MK-Ferguson/Jacobs Engineering Group was hired as cleanup contractor. 
Facility and Year Event

\section{U.S. Department of Energy Facilities (Cont.)}

West Valley, New York

1972

1975

1980

1982
Waste reprocessing plant was closed.

Waste overflows from trenches were discovered.

Waste solidification project was established.

DOE assumed responsibility for the site. 